\title{
Aspectos políticos, econômicos e institucionais da exploração e produção de petróleo e gás no Brasil
}

\section{Political, economic, and institutional aspects of oil and gas exploration and production in Brazil}

${ }^{1}$ Universidade do Vale do Itajaí, Itajaí, Brasil.

*Correspondencia: jb.alves@protonmail.com

Resumo. O estudo faz uma abordagem econômica, política e institucional da exploração e produção (E\&P) de petróleo e gás no Brasil desde as explorações precursoras ocorridas no Brasil Império até a descoberta do pré-sal. A conjunção de três episódios recentes (a grave recessão econômica de 2015-16, a derrocada dos preços do petróleo e a Operação Lava-Jato) produziram sérias instabilidades no setor petrolífero. Porém, as alterações no marco regulatório a partir de 2018 e a redução da presença do Estado na economia alavancaram os investimentos no setor que contribuirão para financiar o crescimento econômico do país. Ademais, o setor petrolífero no Brasil ainda tem muito a crescer, visto que menos de $5 \%$ da área sedimentar estão contratados.

Palavras-chave: petróleo; gás; Brasil; Petrobras; pré-sal.

CÓMO CITAR: Alves, J. A. B. e Pollete, M. (2021). Aspectos políticos, econômicos e institucionais da exploração e produção de petróleo e gás no Brasil. América Latina en la Historia Económica, 28(2), 1-31. DOI: 10.18232/alhe.1168 
Abstract. The study takes an economic, political and institutional approach to oil and gas exploration and production in Brazil from the precursor explorations that took place in the Brasil Império to the discovery of pre-salt layer. The conjunction of three recent episodes (the severe economic recession of 2015-16, the fall in oil prices and Operation Lava-Jato) have produced serious instabilities in the oil sector. However, changes in the regulatory framework since 2018 and the reduction of the State's presence in the economy leveraged investments in the sector that will contribute to finance the country's economic growth. Also, the oil sector in Brazil still has a lot to grow, since less than $5 \%$ of the sedimentary area is contracted.

Key words: oil; gas; Brazil; Petrobras; pre-salt.

JEL: N56; O13; P48.

Recebido: 29 de janeiro de 2020.

Aceito: 5 de outubro de 2020.

Publicado: 30 de abril de 2021.

\section{INTRODUÇÃO}

Este estudo analisa o avanço da exploração e produção de petróleo e gás natural no Brasil desde as explorações precursoras do século XIX até a descoberta do pré-sal. Buscou-se discutir as questões políticas, econômicas e as diversas medidas de caráter legais e institucionais que ocorreram no setor de hidrocarbonetos ${ }^{1}$ no país traçando um paralelo ao desenvolvimento econômico do Brasil. Conjuntamente, o estudo objetivou contribuir para fornecer uma visão panorâmica da evolução das políticas relacionadas ao mercado petrolífero do governo brasileiro ao longo do período analisado.

Petróleo é uma matéria-prima estratégica não apenas pela produção de combustível e energia, mas, também pelo fato de que é, e ainda será por muito tempo, o principal insumo da indústria petroquímica mundial. No Brasil, a indústria do petróleo e gás responde por $11 \%$ do Produto Interno Bruto (РIB) nacional e 50\% da oferta interna de energia (Oddone, 2017).

Para melhor contextualização, dividiu-se a exploração, produção e marcos institucionais relativos ao petróleo em cinco períodos, correlacionando-os com os principais aspectos históricoeconômicos do Brasil: a) 1858-1906, quando aconteceram as explorações desbravadoras realizadas por particulares; b) 1907-1952, ciclo no qual ocorreu uma maior participação institucional e organizacional do governo brasileiro; c) 1953-1997, período em que o setor de petróleo esteve sob monopólio estatal da Petróleo Brasileiro s. A. (Petrobras); d) 1998-2007, após a aprovação da chamada Lei do Petróleo que flexibilizou o monopólio da União na exploração e produção de petróleo e gás natural, e abriu o mercado para outras empresas do setor petrolífero competirem com a Petrobras; e) 2008-2018, com a descoberta de petróleo na camada pré-sal, que modificou profundamente o cenário de exploração e produção no Brasil.

Com vistas a investigar as relações entre os diversos atores da indústria petrolífera ao longo do tempo, o método de estudo baseou-se em estudar os fatos econômicos dentro do tempo sóciocultural-cronológico (Richardson, 2015), utilizando-se de pesquisa bibliográfica e documental. Estruturou-se esse texto em oito seções, além dessa introdução. Explanou-se na primeira seção a

\footnotetext{
${ }^{1} \mathrm{O}$ setor de hidrocarbonetos é composto pelas indústrias do petróleo e gás natural.
} 
base teórica na qual está apoiado o setor petrolífero brasileiro. Na segunda seção, contextualizouse a atuação dos demais governos latino-americanos diante do setor petrolífero. As cinco fases da indústria do petróleo no âmbito histórico-político, econômico e institucional no Brasil e América Latina, são dissertadas nas seções seguintes, seguindo-se, as conclusões.

\section{REGULAÇÃO ECONÔMICA DO SETOR PETROLÍFERO}

Buscou-se destacar as principais abordagens que tratam do tema acerca da regulação econômica pelo governo ou agências administrativas independentes cujo fim é a busca de eficiência alocativa, no sentido de remediar falhas de mercado, proteger o meio ambiente, entre outros.

Na segunda metade da década de 1990, o Brasil adotou um modelo de liberalização econômica visando aumentar a participação brasileira no comércio internacional, com a extinção de políticas protecionistas à indústria e implementação de reformas voltadas para o mercado. Esse movimento ocorreu também em vários países da América Latina. Nesse cenário, o Estado interventor ou executor, deu lugar ao princípio do Estado regulador do mercado, como no caso do petróleo, com a criação da Agência Nacional do Petróleo, Gás Natural e Biocombustíveis (ANP), ${ }^{2}$ uma autarquia federal vinculada ao Ministério de Minas e Energia, que executa a política nacional para o setor, com foco na garantia do abastecimento de combustíveis e na defesa dos interesses dos consumidores. Nesse novo ambiente institucional, a ANP fornece a estabilidade necessária tanto para atração do capital privado, e à minimização dos riscos de interferência política ou de mudanças constantes de regras para a exploração e produção de hidrocarbonetos no Brasil (Caselli, 2011; ANP, 2018a).

Dessa forma, a intervenção do Estado nas relações privadas seria justificada, pois zelaria pelo bem-estar social (Joskow e Noll, 1981), a qual possui amparo inclusive na Constituição Federal do Brasil. No entanto, cabe salientar que o Estado pode ser uma ameaça para a atividade econômica de uma sociedade conforme a teoria da captura do regulador, onde a agência reguladora se torna controlada pela indústria ao longo do tempo (Stigler, 1971). Não obstante, os governantes que controlam a política regulatória podem tomar decisões de acordo com interesses comerciais ou políticos que beneficiem grupos que dominam o setor industrial daquela agência reguladora, e dessa forma, não priorizar o interesse público (Peltzman, 1976). Nesse contexto, o Estado possui poder coercitivo para alocar recursos, além de efetuar a regulação econômica e de policiar cartéis em diversos setores da economia (Posner, 1974). Assim, conforme Bagnoli (2011) "A importância da regulação como forma do Estado intervir no âmbito econômico para promover os valores sociais, estaria relacionada com a evolução e transformação do Estado de Bem Estar Social para um Estado Regulador" (p. 53). O fato é que, as atribuições das agências reguladoras só cresceram com o passar dos anos, atingindo todos os mercados econômicos. Atualmente, não apenas fixam preços de bens e serviços ofertados em regime de monopólios naturais, mas, também atuam na expansão dos mercados sob sua jurisdição e buscam promover a concorrência no setor (Beesley, 1997).

${ }^{2}$ A Lei num. 9.478/1997 instituiu a Agência Nacional do Petróleo, Gás Natural e Biocombustíveis (ANP) como o órgão regulador das atividades que integram as indústrias de petróleo e gás natural e de biocombustíveis no Brasil. A implantação da Agência, se deu posteriormente pelo Decreto num. 2.455/1998. 


\section{GOVERNOS LATINO-AMERICANOS E SETOR PETROLÍFERO}

A indústria petrolífera exerce grande influência na política, na economia e no aspecto institucional dos países latino-americanos detentores de reservas de hidrocarbonetos. Isso ocorre, tanto pela magnitude dos investimentos ao longo da cadeia produtiva do petróleo e gás, como pelas rendas geradas para as petroleiras e para os países onde essas companhias operam.

A década de 1920 na América Latina, foi de capitalismo aberto, em expansão e competitivo, do qual as empresas petrolíferas estrangeiras aproveitaram ao máximo. Naquela ocasião havia uma rivalidade entre os Estados Unidos e Grã-Bretanha sobre os recursos petrolíferos nas Américas, o que despertou uma maior conscientização nesses países latino-americanos sobre sua importância (Philip, 1982; Bucheli, 2010). A década de 1930, no entanto, foram anos de recuo e concentração. O petróleo tornou-se abundante e a indústria buscou evitar as consequências do excesso de oferta. A gestão, em vez da descoberta tornou-se a chave para o comportamento das companhias petrolíferas. Nesse contexto, as petroleiras buscavam a integração vertical da produção, transporte e refino na busca de lucros quase monopolistas. No Peru, México, Venezuela, Colômbia e Argentina, as companhias obtiveram notáveis taxas de retorno. Uma das maiores companhias petrolíferas do mundo, a Standard Oil Company of New Jersey (Jersey Standard) gerou até 40\% de seus lucros globais de petróleo em território latino-americano, nos anos seguintes à Primeira Guerra Mundial (Philip, 1982).

Numa reação ao domínio do mercado pelas grandes companhias petrolíferas, alguns países da América Latina reformularam suas legislações aumentando o controle estatal sobre o petróleo, o que inevitavelmente levou a confrontos entre os governos latino-americanos e as petroleiras estrangeiras, e seus governos de origem (Bucheli, 2010). À vista disso, em 1917 o México declarou o subsolo do país como propriedade nacional, a Colômbia reformou suas leis de subsolo em 1919, e a Argentina criou em 1922 sua primeira empresa pública verticalmente integrada, a petroleira Yacimientos Petrolíferos Fiscales (YPF). Esses movimentos caracterizaram o início da política de intervenção estatal como forma de apropriação da renda criada pelo petróleo (Bucheli, 2010; Melo e Oliveira, 2015).

Não obstante, nas décadas seguintes, alguns governos tomaram medidas mais agressivas. A Bolívia nacionalizou em 1937 as propriedades da Jersey Standard; na Venezuela, após 1935 as companhias foram obrigadas a pagar royalties e a contratar mão-de-obra doméstica; no México, a tensão entre as multinacionais de petróleo e o governo durante a Revolução Mexicana (19101920) culminou com a expropriação de todas as multinacionais de petróleo, seguido pela criação da Petróleos Mexicanos (Pemex) em 1938; em 1968 o Peru nacionalizou os ativos da International Petroleum Company (IPC), uma subsidiária da Jersey Standard; e em 1976 a Venezuela nacionalizou a indústria petrolífera e criou a empresa estatal Petróleos de Venezuela (PDVSA) (Bucheli, 2010).

Dessas acepções, pode-se ressaltar que grande parte do século xx na América Latina foi marcada pela expropriação de ativos petrolíferos estrangeiros e nacionalização do setor, o desenvolvimento da indústria de petróleo e gás oscilou conforme o tamanho da economia de cada país, associado aos ciclos das commodities produzidas e exportadas, e a maturidade política, institucional e de governança. Nesse sentido, Monaldi (2015) cita que os incentivos proporcionados por ciclos de preços, ciclos de investimento, financiamentos e instituições, são fundamentais para entender as ondas de nacionalismo de recursos e liberalização. A América Latina tem sido mais propensa a esse tipo de volatilidade política, possivelmente devido à combinação de democracias faccionais, estado de direito fraco e alta desigualdade desenfreada. 


\section{EXPLORAÇÕES DESBRAVADORAS NO BRASIL: 1858-1906}

A busca por petróleo no Brasil em seus primórdios ocorreu de maneira dispersa e alheia ao caráter científico, dado que decorria basicamente de efluências de óleo e gás que emanavam em algumas regiões do país. No início, sob a égide da Constituição Política do Império do Brasil outorgada por Pedro I em 1824, não havia citação ou regras em relação a jazidas ou o subsolo (Quintans, [ca. 2012], o que denotava a não preocupação do Império brasileiro em relação a exploração do solo e do subsolo. O regime de mineração era o dominial, ou seja, fundado no conceito de que os recursos naturais do subsolo constituíam uma res communis, em outras palavras, um conjunto de bens pertencentes à Nação ou ao Estado (Barbosa, 2004). Nesse contexto, a legislação de minas do período imperial não era específica e se apoiava tanto no texto constitucional de 1824, como na Lei de Terras de 1850, que estabelecia que o subsolo era propriedade do Estado, nada obstante, fosse explorado por particulares.

Os primeiros decretos imperiais concedendo direito de extração de minerais no Brasil ocorreram durante o Segundo Reinado (1840-1889), período em que o Brasil foi governado por Dom Pedro II. As concessões tinham por finalidade encontrar material para o fabrico de óleo ou gás de iluminação. Nesse âmbito, em 1858 José de Barros Pimentel adquiriu mediante o Decreto 2.266 o direito de extrair carvão e xisto betuminoso nas margens do Rio Marau, na Província da Bahia. ${ }^{3}$ No mesmo dia, o Decreto 2.267 concedeu ao norte-americano Frederico Hamilton Southworth o direito de extrair o mineral denominado turfa nas margens do rio Acarahy, na Província da Bahia. ${ }^{4}$

O primeiro Decreto Imperial que faz menção à extração de petróleo em terras brasileiras foi o de num. 3.352-A/1864, o qual concedeu ao inglês Thomaz Denny Sargent prerrogativa pelo prazo de 90 anos para, por si ou por meio de uma companhia, extrair turfa, petróleo e outros minerais nas comarcas do Camamu e Ilhéus, na Província da Bahia. ${ }^{5}$

Houve ainda nessa época, várias outras concessões do governo do Império do Brasil para pequenos exploradores em busca de "[ . . . jazidas de petróleo, geralmente junto com a busca por carvão e outros minerais com o objetivo de fabricação de 'óleo e gás iluminantes' para substituir o óleo obtido a partir da pesca de baleias, que começava a se tornar escasso e caro em razão do aumento da demanda mundial pelo óleo" (Morais, 2013, p. 21). Todavia, essas concessões não apresentaram nenhuma descoberta importante e ocorreram na Bahia, Maranhão e outras províncias do Nordeste, seguidas por explorações registradas no interior de São Paulo nos arredores de Rio Claro e na região da Bacia do Paraná (Lucchesi, 1998; Morais, 2013). "Os brasileiros e/ou

${ }^{3}$ Decreto Imperial num. 2.266, 2 de outubro de 1858, Coleção de Leis do Império do Brasil, vol. 1, pt. II, p. 480. "Concede a José de Barros Pimentel faculdade para, por meio de huma Companhia, extrahir o mineral bitunioso, que denomina Bituminous Shalk, proprio para fabrico de gaz de illuminação, e carvão de pedra, em terrenos situados na margem do rio Marahú da Provincia da Bahia”.

${ }^{4}$ Decreto Imperial num. 2.267, 2 de outubro de 1858, Coleção de Leis do Império do Brasil, vol. 1, pt. II, p. 48. "Concede a Frederico Hamilton Sauthworth faculdade para extrahir o mineral, que denomina Illuminating vegetable turf, proprio para o fabrico de gaz de Illuminação, em terrenos situadas nas margens do rio Aracahy da Provincia da Bahia”.

${ }^{5}$ Decreto Imperial num. 3.352-A, 30 de novembro de 1864, Coleção de Leis do Império do Brasil, vol. 1, pt. IIadt., p. 12. "Concede a Thomaz Denuy Sargent faculdade pelo prazo de noventa annos para, por si ou por meio de uma Companhia, estrahir turfa, petroleo e outros mineraes nas Comarcas do Camamú e Ilhéos, da Provincia da Bahia”. 
estrangeiros que adquiriam essa concessão geralmente estavam envolvidos de modo relevante no meio social e político, sendo coronéis, bacharéis (advogados), políticos, ou empenhados na construção de estradas de ferro pelo país" (Peyerl, 2014, p. 47).

Alguns marcos estruturaram a prospecção e exploração de minerais nessa fase; em 1875 foi criada a Comissão Geológica do Império, chefiada pelo geólogo canadense-americano Charles Frederick Hartt, incumbida de realizar um mapa geológico do país a fim de identificar as riquezas minerais no território brasileiro (Andrade, 2018). A partir de $1876 \mathrm{com}$ a fundação da Escola de Minas de Ouro Preto, em Minas Gerais, passou-se a formar mão-de-obra mais especializada e detentora de algum conhecimento científico para se buscar petróleo. Após a Proclamação da República em 1889, segundo Peyerl (2014), houve apenas uma concessão de iniciativa particular e nota-se que "Outras concessões preexistentes se modificam pelo acréscimo de novas observações, prorrogação, ou pela inclusão, junto ao nome do outorgado, das palavras companhia ou sociedade, demonstrando modificações na prática econômica do país" (p. 48).

Levando-se em consideração os aspectos analisados, o período imperial brasileiro foi marcado:

[...] pela exploração de fontes de petróleo ou afins disponíveis em afloramentos naturais, às margens de rios, em mangues, minando de pedras, sem uma maior necessidade de investigação mais profunda do subsolo para a sua descoberta e inicial exploração [e esteve concentrada geograficamente], ... no litoral baiano, apresentando ao final do Império o crescimento das explorações em São Paulo, no Vale do Paraíba, acompanhando o desenvolvimento industrial da região que recebia o capital excedente da lavoura cafeeira [...] (Reis, 2020, p. 8).

Em 1891, quando da promulgação da primeira Constituição da República -inspirada nos princípios liberais da Constituição dos Estados Unidos da América (EUA)-, "As minas pertencem ao proprietário do solo, salvo as limitações estabelecidas por lei, a bem da exploração das mesmas". ${ }^{\circ}$ Assim, se estabeleceu um novo regime denominado fundiário, também chamado regime da acessão, no qual não apenas o solo pertencia ao proprietário, mas, também as minas existentes em seu interior, salvo se desapropriada por necessidade ou utilidade pública, mediante indenização prévia. Nesse mesmo ano, transcorreram as primeiras pesquisas realizadas por uma firma inglesa que instalou uma sonda no litoral de Alagoas (Mello, 1969). Consta que em fins do século xix populações das praias do norte alagoano usavam para fins doméstico pequenas porções de xisto betuminoso que ali surgiam.

No entanto, o primeiro poço brasileiro foi perfurado somente em 1897 pelo fazendeiro Eugênio Ferreira de Camargo no município de Bofete, no estado de São Paulo. O poço atingiu a profundidade de 488 metros, mas, produziu somente $0.5 \mathrm{~m}^{3}$, algo como dois barris de petróleo (Dias e Quaglino, 1993). Apesar de seu insucesso, essa iniciativa pioneira destaca-se, sobretudo, por seu caráter inteiramente privado, conduzida segundo os princípios da legislação liberal, então, vigente no país (Dias e Quaglino, 1993; Lucchesi, 1998; Thomas, 2001).

O fato é que, o ciclo imperial da história do petróleo:

${ }^{6}$ Constituição da República dos Estados Unidos do Brasil, 1891, art. 72, parágrafo 17, alínea "a”. 
[...] dependeu da iniciativa de empreendedores privados, em especial ingleses, que já atuavam na exploração econômica do carvão e no negócio de ferrovias no Brasil [sem que houvesse descobertas proeminentes, e naturalmente, o]... negócio do petróleo no Brasil chegava ao seu fim, ... sem nenhuma expressão do ponto de vista geopolítico e comercial em termos internacionais (Reis, 2020, p. 8).

A partir de 1897 passou a haver o domínio de iniciativas privadas por meio de companhias estrangeiras que se estenderam pela década de 1910 (Peyerl, 2014).

\section{MAIOR PARTICIPAÇÃO INSTITUCIONAL DO GOVERNO: 1907-1952}

Um aumento de perfuração de poços com profissionais mais especializados aconteceu quando da criação do Serviço Geológico e Mineralógico Brasileiro (sGMB) em 1907. No entanto, conforme Peyerl (2014), o Brasil no início da década de 1920, não era visto como um território promissor em petróleo, "O que induziu muitas empresas estrangeiras a optarem pela concentração dos seus esforços no objetivo de tornar o Brasil um país importador de petróleo” (p. 27). Nessa mesma década, duas companhias estrangeiras foram autorizadas a operarem no Brasil, a Standard Oil Company of Brasil,7 em 1912, e a The Anglo Mexican Petroleum Products Company, em 1913 (Peyerl, 2014).

Na primeira metade do século xx o crescimento econômico brasileiro se dava a partir da transição de uma economia agroexportadora ancorada na cafeicultura, para uma economia industrial alavancada por um Processo de Substituição de Importações (PSI), ${ }^{8}$ inicialmente estimulado pelo Governo Provisório de Getúlio Vargas em 1930, que inseriu gradualmente na economia uma gama de produtos produzidos no país em substituição aos produtos importados.

No surgente setor industrial brasileiro nesse período, destaca-se nessa época, a figura do escritor Monteiro Lobato como empresário protagonista, que estava entusiasmado com o progresso dos EUA, onde foi adido comercial do Brasil em Nova Iorque em 1927. ${ }^{9}$ Quando retornou ao Brasil em 1931, Lobato afastou-se temporariamente da literatura e da atividade de editor para vivenciar experiências no mundo industrial, crente que o crescimento das indústrias do ferro e do petróleo era decisivo para o desenvolvimento econômico brasileiro (Projeto Memória, 1998; Lobato, em Abreu et al., 2001). Lobato realizou uma série de conferências, visando promover a venda de ações de uma companhia petrolífera para levantar capital. Numa dessas reuniões, em Belo Horizonte, disse: "Compreendi ser o petróleo a grande coisa, a coisa máxima para o Brasil,

${ }^{7}$ A presença da Standard Oil Company of Brasil remete ao Decreto num. 2.471/1897, que concedeu autorização a Empresa Industrial de Petróleo, que posteriormente, seria denominada de Standard Oil Company of Brazil (Peyerl, 2014).

${ }^{8}$ A industrialização da economia nacional teve como alavanca o crash da bolsa de valores de Nova Iorque em 1929, o qual causou uma depressão econômica nos EuA e provocou uma violenta queda nas exportações de café (à época representava $60 \%$ da pauta de exportações), cujo principal comprador era os EUA. A crise no setor cafeeiro, responsável pelo dinamismo da economia e pela geração de renda interna, levou o país a uma severa crise econômica e a um estrangulamento externo, provocado pela redução acentuada de divisas de receitas das exportações, de empréstimos e financiamentos estrangeiros.

${ }^{9}$ Indicado pelo então Presidente Washington Luís. 
a única força com elementos capazes de arrancar o gigante do seu berço de ufanias" (Projeto Memória, 1998, para. 9). Sua visão de negócios levou-o a fundar em 1931 o Sindicato Nacional de Indústria e Comércio, voltado para a exploração do ferro e a Companhia Petróleos do Brasil. ${ }^{10}$

No que tange as normas institucionais para o setor mineral do Brasil, o Governo Provisório nacionalista de Vargas revogou a Constituição republicana de 1891 ao outorgar a Carta de 1934 que eliminou o regime fundiário e estabeleceu o regime dominial, o qual atribuiu a propriedade do subsolo ao Estado. Autorizações ou concessões seriam conferidas exclusivamente a brasileiros ou a empresas organizadas no Brasil, ressalvando ao proprietário, preferência na exploração ou coparticipação nos lucros. Em 1934 o Departamento Nacional da Produção Mineral (DNPM) veio a estruturar ainda melhor a atividade de exploração de petróleo juntamente com já existente Serviço Geológico e Mineralógico Brasileiro de 1907, muito embora, o setor petrolífero ainda carecesse de recursos e de um órgão a ele dedicado (Lucchesi, 1998).

Um outro marco institucional nesse período foi o Decreto Federal num. 24.642/1934 que sistematizou a legislação mineral e recebeu a denominação oficial de Código de Minas ${ }^{11}$ que consolidou o direito minerário no Brasil, cujos principais conceitos e institutos ainda orienta esse ramo do direito até os dias atuais (Dias e Quaglino, 1993; Andrade, 2011). Uma mudança contundente na legislação mineral viria com a Constituição de 1937, outorgada durante o Estado Novo, que era um regime autoritário e centralizador. Essa Carta, segundo Quintans [ca. 2012] "[...] determinou a nacionalização progressiva das minas, jazidas minerais e quedas d'água ou de outras fontes de energia [...]" (p. 6). Assim, nada podia ser feito sem autorização federal e a propriedade do subsolo continuava ligada à do solo. No ano de 1938 o governo brasileiro por meio do Decreto-Lei num. 395 constituiu o Conselho Nacional do Petróleo (CNP) para administrar a política do petróleo do país, o qual era subordinado diretamente à Presidência da República, e responsável por avaliar os pedidos de pesquisa e lavra de jazidas de petróleo ${ }^{12}$ (Agência Petrobras, 2006). Destaca-se conforme Andrade (2018), que o corpo de técnicos do cNP à épocBahia20a era insuficiente para expandir a indústria do petróleo no país, o que levou o CNP a investir na formação de seus próprios profissionais.

Além da instituição do GNP, esse decreto conferiu o status de utilidade pública ao petróleo tratando-o, portanto, de maneira distinta dos demais recursos minerais, em face desse ser a fonte principal de energia para a realização do transporte, especialmente aéreo e rodoviário e indispensável à defesa militar e econômica do país. Assim, o cNP cuidava da política relacionada a ele, enquanto o DNPM legislava sobre os demais recursos minerais.

Em 1939 duas sondagens realizadas pelo DNPM em Lobato ${ }^{13}$ nos arredores de Salvador na Bahia atingiram respectivamente as profundidades de $71.91 \mathrm{~m}$ e $228.38 \mathrm{~m}$, sendo que esta última encontrou petróleo (Peyerl, 2014). Essa descoberta fez com que o Conselho Nacional do Petróleo concentrasse esforços nesse campo de exploração, porém, ao final de 17 poços perfurados -sete

${ }^{10}$ Empresa privada de capital aberto que teve a metade das ações subscritas em apenas quatro dias, recebendo destaque da imprensa. Posteriormente, Monteiro Lobato promoveu ainda, o lançamento de várias outras companhias, como a Companhia de Petróleo Nacional, a Companhia Petrolífera Brasileira e a Companhia Brasileira de Petróleo Cruzeiro do Sul (Neves, 1948; Carnio, 1997; Projeto Memória, 1998; Lobato, em Arias et al., 2001).

${ }^{11}$ Esse código foi processado no Ministério da Agricultura, e estabelecia que todas as minas e jazidas que até determinado prazo fossem manifestadas, eram reconhecidas como propriedade privada, ao passo que todas as demais, ainda não descobertas ou não manifestadas, passariam ao domínio público (art. 5).

12 O Decreto-lei num. 538/1938 organizou o Conselho Nacional de Petróleo e definiu suas atribuições.

${ }^{13}$ Essa localidade de Lobato na Bahia, não tem qualquer relação com o sobrenome do escritor Monteiro Lobato. 
com óleo e 10 secos- em quatro anos de atividades, o poço responsável pela descoberta rapidamente perdeu vazão e o campo foi considerado subcomercial (Dias e Quaglino, 1993; Thomas, 2001; Agência Petrobras, 2006). Importante ressaltar que Lobato, embora sem apelo comercial, causou enorme entusiasmo e incitou o fervor nacionalista, peculiar da era Vargas, o que levou o CNP a contratar firmas estrangeiras para perfuração e prospecção sísmica com cláusula de treinamento de técnicos. O Decreto-lei num. 1.985/1940, denominado Código de Minas, definiu, normatizou os direitos e intervenção do Estado sobre as jazidas e minas. O Código de Minas de 1940 vigorou até 15 de março de 1967, data em que foi promulgado por meio do Decreto-lei num. 227/1967, o Código de Mineração ainda vigente (Barbosa, 2004). Finalmente, em 1941 descobriu-se o primeiro campo comercial de petróleo do país em Candeias, ainda hoje em atividade $^{14}$ (ver figura 1).

\section{FIGURA 1. C1 - PRIMEIRO POÇO DE PETRÓLEO DO BRASIL - CANDEIAS (BA), 1941}

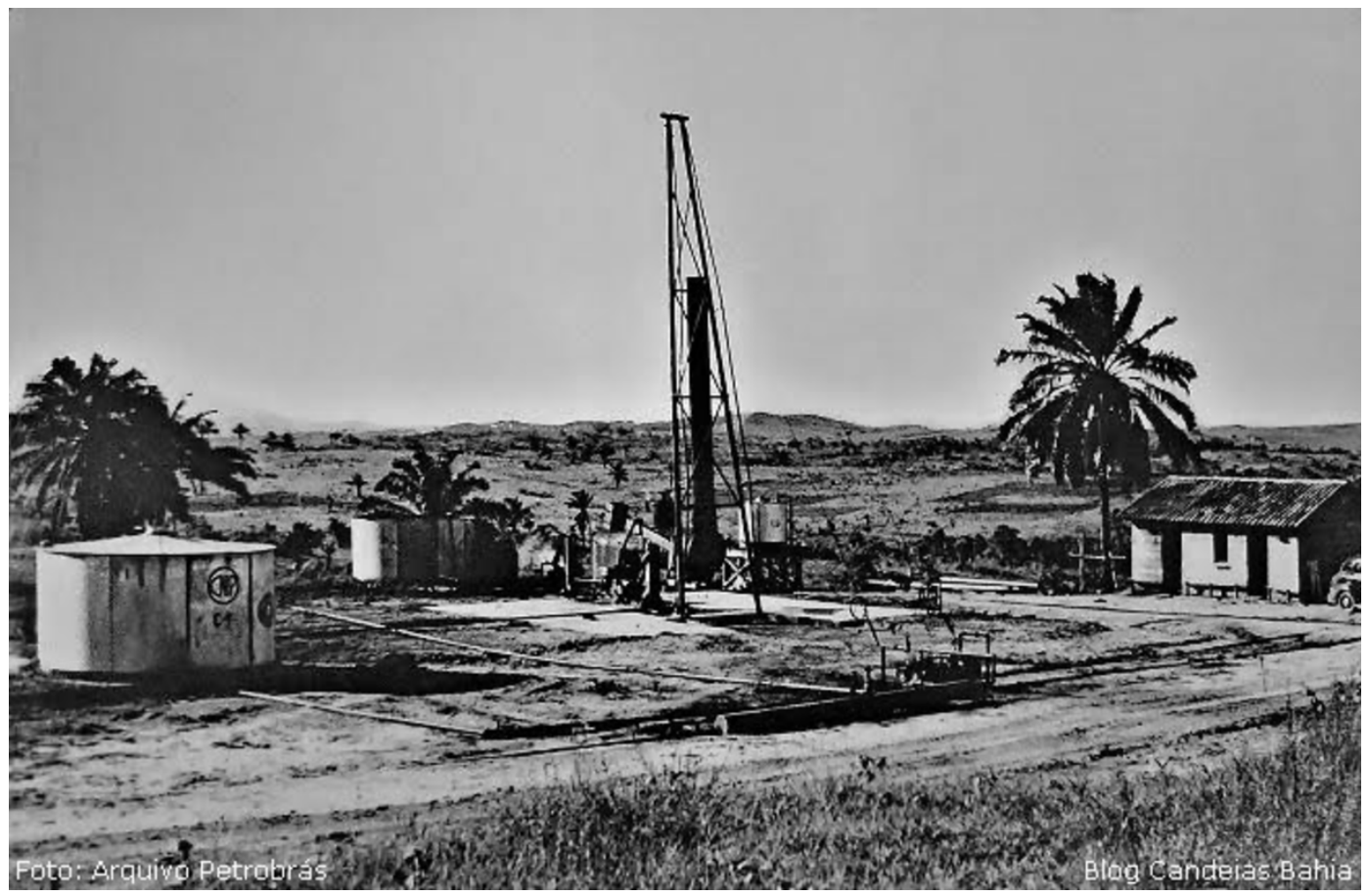

Fonte: Candeias Bahia (2018).

O período entre os anos de 1941 e 1953 foi promissor, pois, enfim jorrou comercialmente petróleo em terras brasileiras e a atividade ganhou com a descoberta de outros campos de petróleo e gás ${ }^{15}$ no Recôncavo Baiano (Dias e Quaglino, 1993; Lucchesi, 1998; Thomas, 2001;

${ }^{14}$ Mais informações; Cf. https://petrobras.com.br/pt/nossas-atividades/principais-operacoes/bacias/bacia-doreconcavo.htm

15 Aratu e Itaparica (em 1942), Dom João (em 1947), Pedras (em 1950) e Água Grande (em 1952). Os campos de gás de Mata de São João foram descobertos em 1951, e, sempre seguindo para o norte do Recôncavo, foi descoberto Pojuca (em 1953). 
Bastos, 2017). Em 1947, impulsionado pela descoberta de petróleo na Bahia, o governo contratou a empresa norte-americana M. W. Kellog para fazer o projeto e a construção no estado da Bahia, da Refinaria Nacional do Petróleo ${ }^{16}$-a primeira do Brasil- inaugurada em 1950 (Agência Petrobras, 2006).

Nessa fase, o petróleo ganhou destaque no planejamento econômico do país com a publicação do Decreto-lei mun. 3.236/1941, conhecido como Código do Petróleo, que foi um marco norteador da exploração e produção de petróleo. Esse decreto garantiu à União a propriedade de todas as jazidas de petróleo e gases naturais encontradas em território nacional. $\mathrm{O}$ viés monopolístico do setor ficou demonstrado no art. 27 desse código, que facultava à União reservar zonas presumidamente petrolíferas, dentro das quais não haveria permissão para pesquisa ou lavra. $\mathrm{O}$ final desse período da história do petróleo no Brasil, foi marcado pelo término do regime ditatorial imposto pelo Estado Novo entre 1936 e 1945, após a renúncia do presidente Getúlio Vargas em 1945. Nesse ano, a produção de petróleo nos campos baianos ainda era pequena e as tentativas de desenvolver grandes refinarias estatais fracassaram.

A Constituição brasileira de 1946 promulgada no governo do general Eurico Dutra, já num ambiente redemocratizado, consentia a exploração dos recursos minerais, inclusive petróleo por brasileiros e sociedades, desde que fossem organizadas no país (art. 139); ou seja, companhias estrangeiras estavam proibidas de operar no setor mineral, entretanto, não havia restrição a que estrangeiros organizassem essas companhias. Todavia, a ingerência da União no domínio econômico estava prevista no art. 146 da nova Constituição, onde poderia, mediante lei especial, intervir no domínio econômico e monopolizar determinada indústria ou atividade.

Nessa conjuntura, em 1947 Dutra designou uma comissão encarregada de rever as leis e formular as diretrizes para a exploração do petróleo, cujo documento resultante ficou conhecido como Estatuto do Petróleo, que atestava o princípio da utilidade pública do produto, mas considerava impossível a completa nacionalização por falta de verbas, de técnicos especializados e de condições gerais, e permitia a participação do capital estrangeiro no setor. O Estatuto quando publicado, descontentou tanto os nacionalistas, que defendiam o monopólio estatal integral, como os liberais favoráveis a concorrência no setor, e ainda, as grandes companhias internacionais interessadas na exploração do petróleo brasileiro, a exemplo de como já vinham atuando na Venezuela (Moreira e Lamarão, 2003). O conflito entre nacionalistas e liberais se tornou uma das maiores cruzadas políticas da história brasileira, cujo mote era "O petróleo é nosso", e tinha por objetivo contrariar a ideia até então, de que apenas grandes consórcios internacionais teriam capacidade de montar uma indústria petrolífera no Brasil (Agência Petrobras, 2018). Fato é que, pouco se investia e quase nada se descobria de petróleo no Brasil. Não obstante, enquanto ocorria esse conflito ideológico no Brasil, Peyerl (2014) cita que países como a Venezuela e Bolívia já avançavam na descoberta e produção de petróleo. Portanto, "O resultado de todos estes fatores foi o controle estatal do petróleo antes de ele ser descoberto no Brasil, e uma companhia estatal monopolizadora antes de criada uma indústria petrolífera digna do nome”. (Smith, 1978, pp. 17-18).

Também, nesse conturbado período entre 1945 e 1950, o abastecimento de derivados de petróleo importados no Brasil começava a pressionar de forma crescente as reservas cambiais do país. A importação de derivados de petróleo em 1948 chegou a representar 44\% do valor de todas as matérias-primas importadas pelo Brasil (ver figura 2).

${ }^{16}$ Atualmente incorporada à Petrobras e rebatizada em 1957 como Refinaria Landulpho Alves (RLAM). 
FIGURA 2. VALOR DA IMPORTAÇÃO DE DERIVADOS DE PETRÓLEO - 1940-1960

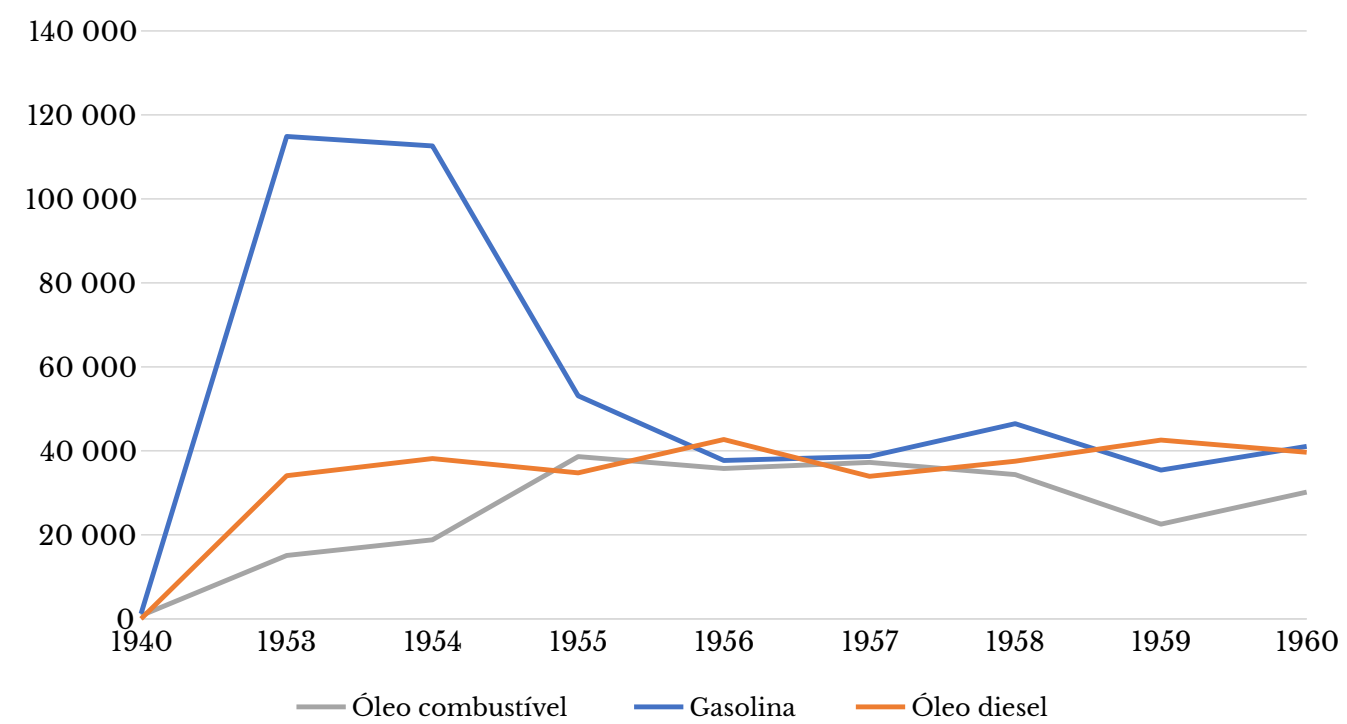

Nota: Os valores reproduzem os publicados em Instituto Brasileiro de Geografia e Estatística (1990), de 1930 a 1946, e os do Banco Central do Brasil, a partir de 1947. As taxas de câmbio até 1941 se referem a mil-réis por dólar americano e cruzeiros da reforma de 1942 por dólar americano a partir desse ano publicadas em Abreu (1990). Taxas de câmbio comercial RS/US\$: 1947-2000 se referem aos valores de compra e venda em fim de período e na média do ano do câmbio comercial entre a moeda nacional (em reais) e o dólar americano.

Fonte: Elaboração própria baseado em Instituto Brasileiro de Geografia e Estatística (1990).

Em 1950 o valor que o país pagava pela importação de petróleo bruto era 200 milhões de dólares e equivalia ao que o país arrecadava com toda a exportação de café (Agência Nacional, 2015). Em relação ao Estatuto do Petróleo, dado que este precisava ser regulamentado por leis ordinárias, a mobilização nacionalista pelo petróleo conseguiu impedir sua aprovação no Congresso Nacional, o que culminaria na criação da companhia estatal Petrobras em 1953, embora o Senado da República tenha sido favorável a participação da iniciativa privada em toda a cadeia produtiva petrolífera. Nesse contexto, cabe citar o intenso debate ocorrido no Senado brasileiro, polarizado por dois grupos antagonistas: por um lado, os senadores defensores do monopólio estatal do petróleo e toda a cadeia de produção e de outro, aqueles que defendiam a participação da iniciativa privada, incluindo empresas estrangeiras, na exploração e refino. Interessante notar, que o cerne ideológico sobre a exploração e produção de petróleo ainda é o mesmo no Brasil de hoje. Dessa forma, as palavras do então senador Assis Chateaubriand em 1953, à época favorável à participação da iniciativa privada no setor petrolífero encaixariam perfeitamente no contexto do senado brasileiro da atual década de 2010, como citado em Westin (2014):

Se é preciso converter o Brasil num produtor e exportador do óleo em bruto e produtos acabados, o caminho mais rápido e produtivo é o da iniciativa privada. Os Estados Unidos, o Canadá, o Reino Unido e a Venezuela dão à palavra nacionalismo o sentido de construção da grandeza nacional, em vez do jacobinismo, cuja tradução se cristaliza 
no ódio e no medo da cooperação com as nações mais adiantadas. Enquanto o venezuelano enriquece extraindo e industrializando o petróleo, nós nos empobrecemos discutindo, como bizantinos, quem deverá perfurar poços e construir refinarias (p. 7).

Cabe destacar que, a criação da Petrobras veio de forma tardia comparada a outras petroleiras estatais na América Latina como a YPF na Argentina, e a Pemex no México.

\section{O MONOPÓLIO ESTATAL DO PETRÓLEO: 1953-1997}

Durante o governo de Getúlio Vargas que havia retornado à presidência da República com grande apoio popular no início de 1951, entrou em vigor a Lei Federal num. 2004/1953 que constituiu o monopólio do petróleo no Brasil para a pesquisa e lavra das jazidas de petróleo. Essa lei monopolizou também as atividades de refinação do petróleo nacional ou estrangeiro, transporte marítimo do petróleo bruto de origem nacional ou de seus derivados produzidos no país, transporte por meio de condutos de petróleo bruto e seus derivados, assim como de gases raros de qualquer origem (a lei não fez menção clara a gás natural). Ressalta-se que, a lei excluiu do monopólio as refinarias e oleodutos que já estavam em funcionamento no país. ${ }^{17}$

O monopólio do setor seria exercido pela União, controlado e fiscalizado pelo Conselho Nacional do Petróleo, e executado pela Petrobras e suas subsidiárias. Curiosamente, a fundação da Petrobras fundada como uma empresa de economia mista controlada majoritariamente pela União, não estabelecia o monopólio estatal -que era uma das principais teses nacionalistas- e permitia que até 1/10 das ações da empresa holding ficasse em mãos de estrangeiros. ${ }^{18}$ Importante salientar, que a Petrobras também havia sido criada para resolver o problema da alta dependência brasileira do petróleo importado, dado que ao longo da década de 1940 o Brasil aumentou de forma substancial a importação de derivados de petróleo (Petrobras, em Abreu et al., 2001). Nos seus primeiros anos de atividades a companhia descobriu importantes campos de petróleo em terra em vários estados do Nordeste, porém, em meados da década de 1960 constatou que essas descobertas eram insuficientes para diminuir a sujeição ao petróleo importado (Morais, 2013; Agência Petrobras, 2018).

A demanda por combustíveis continuava a aumentar no país devido ao crescimento industrial em vários setores, principalmente a partir do Governo de Juscelino Kubitschek -1956-1961-, que instituiu o Plano de Metas, considerado o auge do Psi. O plano econômico de Kubitschek foi um período de incentivo à entrada de capital estrangeiro e aumento do consumo, cujo fundamento se dava no estabelecimento de bases de uma economia industrial que provesse bens de consumo duráveis e aumento da produção de bens intermediários, como aço, carvão o cimento, entre outros. ${ }^{19}$ No que tange as metas envolvendo o petróleo, o plano de desenvolvimento econômico de Kubitschek destacava a produção e o refino de petróleo e visava estabilizar o custo das importações no nível registrado em 1956 (US\$ 270 milhões). Ademais, pretendia ainda atender a demanda adicional que seria gerada pela expansão da produção nacional (Agência Nacional, 2015).

17 O governo manteve as autorizações concedidas para as refinarias privadas como Ipiranga, no Rio Grande do Sul, e Manguinhos, no Rio de Janeiro, ambas de pequeno porte.

${ }^{18}$ A lei estabeleceu em seu art. 11 que a União participasse em todo aumento de capital, mantendo ações ordinárias de forma que lhe assegurasse pelo menos $51 \%$ do capital votante.

19 Também houve investimentos estatais em infraestrutura liderados pelos setores de energia e transporte com foco no modal rodoviário com a construção de extensas rodovias substituindo o ferroviário. 
Durante o período 1961-1964 já no governo João Goulart, o Conselho Nacional do Petróleo intensificou sua política nacionalista concedendo à Petrobras em 1962 a exclusividade na importação de petróleo e derivados com objetivo de reduzir o custo das importações. Na realidade, pela condição de empresa monopolista do setor petrolífero, e pelo fato do Brasil estar em meio a seu processo de crescimento econômico, a Petrobras era muito mais do que apenas uma petroleira, ela era o agente propulsor de toda a cadeia produtiva do petróleo. Em 1961 a Petrobras conseguiu a autossuficiência na produção dos principais derivados por meio da construção de várias refinarias pelo país, o que alterou acentuadamente a estrutura das importações no setor. Em 1953 os derivados de petróleo correspondiam a $98 \%$ das compras externas enquanto o óleo cru era $2 \%$; em 1967, o perfil das importações passava a ser $8 \%$ de derivados e $92 \%$ de petróleo bruto (Agência Nacional, 2015).

Na década de 1960, ocorreram alguns importantes marcos na história da Petrobras: a produção de 100 mil bpd, em 1962; a descoberta do campo terrestre de Carmópolis/Sergipe, em 1963; a criação do Centro de Pesquisas e Desenvolvimento Leopoldo Miguez (Cenpes), ${ }^{20}$ em 1963, e a primeira descoberta de petróleo no mar - campo de Guaricema/Sergipe, em 1968 (Agência Nacional, 2015; Agência Petrobras, 2018).

Em relação a legislação, destaca-se na Constituição de $1967,{ }^{21}$ o restabelecimento ao direito do proprietário de participar dos resultados da lavra e a explicitação do monopólio da União na pesquisa e na lavra.

\section{Crises internacionais do petróleo da década de 1970 e o Programa Nacional do Álcool (Proálcool)}

No início dos anos 1970, durante o governo militar no país, o consumo de derivados de petróleo duplicou, impulsionado pelo alto crescimento do PIB. Em 1972 o Brasil importava 80\% do petróleo que consumia e a produção interna de petróleo atendia apenas $23.5 \%$ da demanda aparente. Quando em outubro de 1973 ocorreu a primeira crise internacional do petróleo, a Organização dos Países Exportadores de Petróleo (OPEP) aumentou em cerca de 100\% o preço do petróleo (ver figura 3) impondo ao mundo uma crise de energia que afetou profundamente o Brasil, à época extremamente dependente do petróleo externo.

Nesse panorama, visando diminuir a dependência em relação ao petróleo importado, o governo brasileiro durante o governo do general Ernesto Geisel lançou em 1974 o II Plano Nacional de Desenvolvimento (II PND), fundamentado em grandes investimentos estatais e produção de insumos básicos, bens de capital, infraestrutura, alimentos e energia. "Nesse sentido, em 1975 é lançado o Programa Nacional do Álcool (Proálcool), assinado o acordo nuclear com a Alemanha e adotada a política de contratos de risco entre a Petrobras e empresas estrangeiras para a prospecção de petróleo em território nacional" (Câmara dos Deputados, 2008, para. 29). O Proálcool criado pelo decreto num. 76.593/1975 foi uma alternativa bem sucedida do governo brasileiro como combustível substituto da gasolina no Brasil. Um fator que contribuiu também para a implantação do Proálcool, segundo Péres, Santos e Pompermayer (2010) foi que a indústria canavieira estava com capacidade instalada ociosa.

${ }^{20}$ Responsável pelo desenvolvimento tecnológico nas áreas de exploração, produção e refino de petróleo e gás natural, além de energias renováveis e desenvolvimento sustentável.

${ }^{21}$ Mais tarde editada pela Emenda Constitucional num. 1/1969. 
FIGURA 3. PREÇO DO BARRIL DO PETRÓLEO, US\$

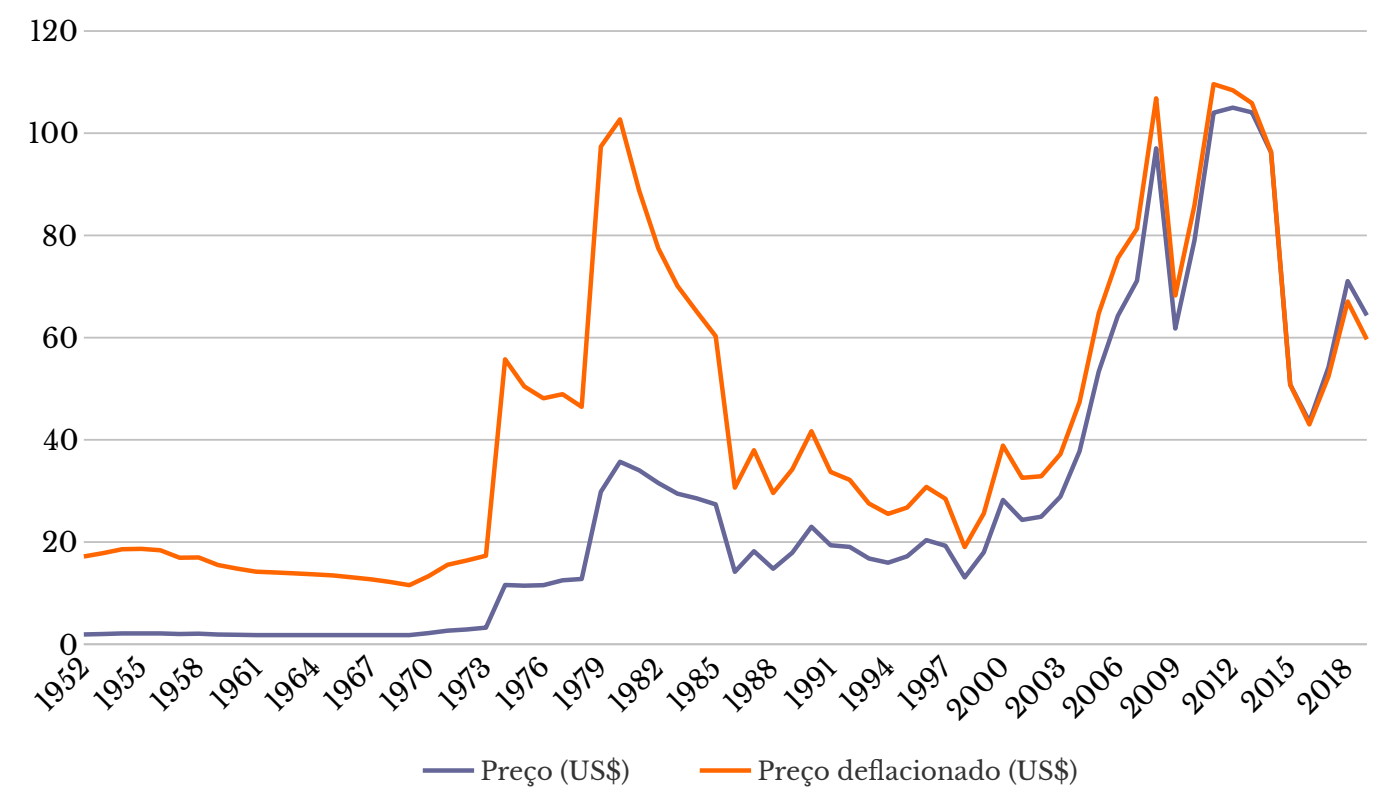

Nota: Preço do Brent em dólares americanos (US\$) deflacionado usando o índice Consumer Price (CPI/EUA); fonte dos dados: IPEADATA (2021); U. S. EIA (2021).

Fonte: Elaboração própria.

Cabe mencionar que, o uso do álcool como combustível automotivo remonta ao primeiro governo Vargas, 1930-1945, apresentada pelo Instituto do Açúcar e do Álcool (IAA). A época o governo federal, por meio do Decreto num. 19.717/1931, tornou obrigatória a mistura de 5\% de álcool à gasolina importada, bem como os veículos pertencentes a órgãos públicos deveriam consumir álcool, ou na falta deste, ao menos uma proporção de 10\% de álcool (Szmrecsányi e Sá, 2010).

Já, durante o Proálcool, a produção e distribuição do álcool combustível, o chamado etanol, ficou a cargo da Petrobras, e os veículos movidos a etanol chegaram a atingir $85 \%$ das vendas totais no Brasil. No entanto, no fim dos anos 1980 alguns fatores como a redução dos preços do petróleo e a recuperação dos preços do açúcar no mercado internacional, desestimularam a produção de etanol ocasionando o encerramento do Proálcool. Não obstante, em 1986 o governo federal retirou o subsídio ao álcool, o que reduziu a rentabilidade média da agroindústria canavieira, estimulando ainda mais o uso da cana para a fabricação de açúcar para exportação (Péres, Santos e Pompermayer, 2010; Szmrecsányi e Sá, 2010).

Apesar do encerramento do programa, Péres, Santos e Pompermayer (2010) citam que o etanol hidratado continua disponível em $90 \%$ dos postos do país e é largamente utilizado como combustível, devido a adição obrigatória à gasolina e ainda pela frota antiga de carros em circulação movidos exclusivamente pelo álcool hidratado. Ademais, "A partir de 2003, com o lançamento dos veículos flexíveis ao combustível, o consumo do etanol hidratado voltou a crescer de modo expressivo, elevando os números de todas as etapas da cadeia de produção e consumo" 
(p. 194). Atualmente, em razão dos investimentos na produção do etanol da cana iniciados com o Proálcool, as energias renováveis possuem um peso significativo na matriz energética do Brasil, contribuindo com $43.4 \%$ do total. A bioenergia da cana sozinha responde por $18.1 \%$ do total (Cortez et al, 2016).

Note-se que, o primeiro choque de petróleo também repercutiu positivamente no Brasil sob dois aspectos: primeiramente, porque influenciou positivamente sobre os preços internacionais das principais commodities produzidas e exportadas, como café, soja entre outras, posto que o petróleo é um importante insumo nos processos produtivos e seu preço impacta o custo, o que, por conseguinte, reflete na oferta. Em segundo lugar, porque os países exportadores de petróleo se beneficiaram amplamente da alta de preços da commodity, e ofereceram empréstimos de médio e longo prazo com juros baixos aos países importadores de petróleo, os chamados petrodólares, dos quais, o Brasil se utilizou largamente para financiar o seu crescimento e aumentar suas reservas internacionais.

Nesse cenário, о PIB brasileiro cresceu de forma considerável no período 1968-1973, em média de $10 \%$ ao ano -puxado pela indústria- o qual ficou marcado na história econômica como o milagre econômico, cujo auge foi em 1973 quando o produto cresceu 14\% com relativa estabilidade de preços. A taxa da inflação no período rodava entre 15 e $20 \%$ ao ano. Em 1974, quando o preço do barril de petróleo foi praticamente quadruplicado, em $252 \%,{ }^{22}$ a trajetória de crescimento do PIB do país acima de 10\% foi descontinuada. Conjuntamente, cresceram os esforços para aumentar a participação do petróleo nacional no consumo brasileiro, tendo em conta que em 1974 o país produzia apenas $20 \%$ do que consumia e o valor das importações brasileiras haviam dobrado nesse ano.

Na década de 1970 a plataforma continental no litoral do Rio de Janeiro passou a merecer atenção especial, dando início a uma produção comercial offshore na bacia de Campos, até então, a maior bacia petrolífera do Brasil (Morais, 2013). No entanto, o Brasil sofreria mais um forte abalo em sua economia, em função da segunda crise internacional do petróleo ocorrida em 1978, quando a produção de petróleo no Oriente Médio reduziu-se intensamente, o que elevou o preço do barril de petróleo de US\$ 14 em 1978 para US\$ 37 em 1980. Quando a cotação do óleo chegou a US\$ 52/barril em 1979, as importações brasileiras de petróleo alcançaram US\$ 10 bilhões, consumindo quase $50 \%$ da receita de exportação, o que provocou um déficit na balança comercial de US\$ 1024 milhões (Instituto Brasileiro de Geografia e Estatística, 1990). Em 1979 houve ainda um aumento contínuo das taxas internacionais de juros, que forçou igualmente, a um aumento da taxa de juros doméstica. Nesse contexto, o investimento privado declinou e o governo cortou investimentos nas empresas estatais.

Na década de 1980 a dependência das importações foi reduzida, e a Bacia de Santos cuja exploração fora iniciada na década de 1970, revelou uma descoberta de campos de gás em águas rasas de até $150 \mathrm{~m}$, feita por uma afiliada da Shell Oil. Nessa década o Brasil ultrapassou a marca dos $500 \mathrm{mil}$ bpd, e a produção atingiu praticamente $50 \%$ do petróleo que o país consumia. Ao final da década, o dispêndio líquido de divisas com importação de óleo e derivados caía para cerca de 3 bilhões de dólares, ante 10 bilhões de dólares em 1981 (Petrobras, em Abreu, et al., 2001; Vieira Filho e Fishlow 2017; Agência Petrobras 2018). No aspecto legal, a Constituição de 1988

22 Os preços médios do barril eram: 1973 (US\$ 3.29) e 1974 (US\$ 11.58). Ver figura 3. 
(Brasil, 2017) manteve a Petrobras como órgão executor do monopólio do petróleo, bem como, do $\mathrm{CNP}^{23}$ como encarregado da fiscalização das atividades e negociações relativas a esse monopólio da União.

\section{Estabilização econômica no Brasil e consolidação da exploração offshore}

Em setembro de 1990 a Petrobras atingiu recorde de produção com 682 mil bpd, e um lucro naquele ano de US\$ 577 milhões, que correspondia a cerca de 3.6 vezes o do ano anterior 160 milhões de dólares-; em julho de 1991 a companhia superou todos os limites mundiais de profundidade na exploração de petróleo offshore (Petrobras, em Abreu et al., 2001). Porém, a forte instabilidade política e econômica nacional do biênio $1992-1993^{24}$ não permitiu que a Petrobras continuasse a lograr êxito em suas atividades. Essa volatilidade cambial e incerteza quanto ao porvir, trouxe diversas consequências que prejudicaram a economia real e impactaram diretamente os preços do petróleo, visto que são cotados em dólar. As expectativas e os preços futuros influenciam o preço real do petróleo, afetando a conjuntura econômica nos diversos países produtores. Além disso, o mercado spot não existe separado do mercado de futuros, haja vista que o preço de petróleo é influenciado e determinado por contratos futuros ou datados.

O cenário econômico doméstico passaria ainda por uma drástica mudança em julho de 1994 quando da implantação do Plano Real durante o governo de Fernando Henrique Cardoso, que propiciou a estabilização da economia, e repercutiu favoravelmente no setor petrolífero no Brasil. Cardoso propôs um conjunto de medidas de caráter liberal e de privatização na economia, as quais, cita Twichell (2015), tinham como objetivo reduzir os subsídios, fazer a economia operar de forma mais eficiente e atrair capital estrangeiro para reabastecer a conta de capital, e melhorar a capacidade fiscal do governo. O sucesso do Plano Real em alcançar a estabilização deu a Cardoso a alavancagem política que precisava para mover uma série de privatizações de empresas em diversos setores econômicos, entre os quais, gás, telecomunicações, eletricidade e mineração que envolvia inclusive a Petrobras. Em 1997 o Congresso rejeitou a privatização total da Petrobras.

\section{A LEI DO PETRÓLEO E FLEXIBILIZAÇÃO DO MONOPÓLIO DA UNIÃO: 1998-2007}

A grande mudança de rumo no setor de petróleo e gás do Brasil teve início com a Emenda Constitucional num. 9/1995, a qual encerrou oficialmente o monopólio público de 40 anos da Petrobras na exploração, ${ }^{25}$ produção, ${ }^{26}$ refino e transporte do petróleo que perdurou de 1954 até 1997 e

${ }^{23}$ O cNP foi incorporado pelo Departamento Nacional de Combustíveis (DNC) em 1990, que por sua vez foi extinto com a criação da ANP em 1998.

${ }^{24}$ Internamente, o impeachment do presidente Fernando Collor, aliado à inflação e dívida externa altas. Em âmbito econômico internacional, a década de 1990 foi marcada por uma série de crises cambiais que afetaram o Brasil em maior ou menor grau, tais como: em 1992-93 houve a 'crise monetária da Europa', com a desvalorização do franco francês e da lira italiana, e a saída da libra britânica do Sistema Monetário Europeu; em 1994 ocorreu a 'crise do México'; em 1996 foi a vez dos chamados Tigres Asiáticos; em 1997 o Japão; e em 2000 a Bolsa da Nova Economia (NASDAQ) entrou em colapso nos EUA.

${ }^{25}$ Exploração se refere ao primeiro poço perfurado para determinar se existem recursos economicamente viáveis via análise de dados geológicos e geofísicos em navios-sonda, cujo processo leva entre 12 e 18 meses.

${ }^{26}$ Produção ocorre após confirmada a viabilidade comercial da descoberta de hidrocarbonetos. Em poços offshore que são a maioria da produção no Brasil utilizam-se geralmente navios flutuantes de produção, armazenamento e transferência (FPSO) ou plataformas flutuantes. 
que viria a ocorrer de fato, com a promulgação da Lei Federal num. 9.478/1997, desde então designada como a Lei do Petróleo. ${ }^{27}$ Essa lei permitiu às demais empresas do setor, desde que constituídas sob as leis brasileiras, e com sede no Brasil, a atuarem em toda a cadeia produtiva do petróleo, popularmente referida como a operação do 'poço ao posto'. Essa permissão se dá em regime de concessão ou mediante autorização do poder concedente, no caso, a União, onde o concessionário explora petróleo ou gás natural por sua conta e risco e, em caso de êxito ${ }^{28}$ possui a propriedade desses bens pagando a carga fiscal correspondente. ${ }^{29}$

Alusivo a isso, a Lei do Petróleo estabeleceu uma nova metodologia para as participações governamentais -recursos pagos pelas concessionárias que exploram hidrocarbonetos no Brasil- definidas pelo Decreto Federal num. 2.705/1998 como sendo: i) bônus de assinatura; ii) royalties; iii) participação especial; e iv) pagamento pela ocupação ou retenção de área. ${ }^{30}$ A lei também instituiu a Agência Nacional do Petróleo, Gás Natural e Biocombustíveis (ANP) como órgão regulador da indústria do petróleo, gás natural, seus derivados e biocombustíveis, vinculada ao Ministério de Minas e Energia (MмE) (Agência Nacional, 2015). Importante citar também, a criação em 1998, da Petrobras Transporte S.A. (Transpetro) que une o sistema Petrobras, sendo a maior empresa de transporte e logística do Brasil com presença na maioria dos estados do país com mais de $14 \mathrm{mil} \mathrm{km}$ de oleodutos e gasodutos, além de 48 terminais -aquaviários e terrestres- e 60 navios. Seu principal cliente é a Petrobras, mas, a empresa presta serviço a diversas distribuidoras e à indústria petroquímica (Agência Petrobras, 2018).

Com o fim do monopólio do setor, em seis anos a produtividade total e de eficiência da Petrobras praticamente duplicou. Isso se deu em parte, devido a ameaça de privatização e à entrada de novas firmas no mercado, que suscitou um aumento na produtividade das empresas públicas, independentemente se a privatização ocorresse ou não (Bridgman, Gomes e Teixeira, 2011, em Vieira Filho e Fishlow, 2017). Em tese, a mudança do ambiente competitivo forçaria a uma melhora dos resultados. Na prática, a privatização não é suficiente para superar os tipos de forças econômicas e políticas que prejudicam a produção, a menos que seja acompanhada por um programa de liberalização. Existem deficiências gerenciais, falta de capacidade administrativa e regulatória e restrições políticas, incluindo o receio de alterar o equilíbrio do poder econômico e político, que levam a privatizações malsucedidas (Walle, 1989). De fato, os adversários mais prováveis para privatizações, provavelmente estão dentro do próprio aparelho estatal.

Com efeito, as reformas de flexibilização de monopólio do setor petrolífero no final da década de 1990 inauguraram uma nova era para a Petrobras, cuja produtividade econômica crescia constantemente, contribuindo fortemente para ao aumento das receitas do governo. Além disso, a Petrobras tem buscado oportunidades no exterior onde as capacidades tecnológicas da companhia lhe dão possui vantagem competitiva (Twichell, 2015). Nesse ambiente, na década de 2000 a Petrobras mudou a estratégia de exploração na bacia de Santos, direcionando seus esforços para

${ }^{27}$ Lei num. 9.478, 6 de agosto de 1997, Presidência da República, Casa Civil. Dispõe sobre a política energética nacional, as atividades relativas ao monopólio do petróleo, institui o Conselho Nacional de Política Energética e a Agência Nacional do Petróleo e dá outras providências. A Lei do Petróleo revogou a Lei Federal 2.004/1953.

28 Na modalidade de concessão, entre 55\% e 65\% da renda são capturados pelo Estado, cf. Agência Nacional (2017).

${ }^{29}$ Somatório dos royalties + participação especial + excedente em óleo + bônus de assinatura + imposto de renda + tributos indiretos.

${ }^{30}$ Decreto num. 2.705, 3 de agosto de 1998, Presidência da República, Casa Civil. Define critérios para cálculo e cobrança das participações governamentais de que trata a Lei num. 9.478, de 6 de agosto de 1997, aplicáveis às atividades de exploração, desenvolvimento e produção de petróleo e gás natural, e dá outras providências. 
águas profundas e ultraprofundas. No ano de 2003 a Petrobras atingiu pela primeira vez uma produção de 2 milhões bpd (Petrobras, em Abreu et al., 2001; Vieira Filho e Fishlow, 2017; Agência Petrobras, 2018). Em 2006 a Petrobras anunciou a descoberta de petróleo em Tupi (atualmente campo de Lula) na Bacia de Santos, na chamada camada pré-sal, explanada na seção seguinte.

A despeito da abertura do mercado para empresas privadas, a Petrobras ainda predomina como a maior empresa no setor de petróleo no Brasil. ${ }^{31}$ Da mesma forma, embora prevista na legislação desde 1997, a abertura do setor de refino nunca aconteceu na prática, fato que impele a Petrobras a exercer um monopólio que determina preços para todas as distribuidoras que operam no Brasil. Essa política de preços, segundo Oddone $(2016$, p. 4) "[. . .] inibiu a construção de refinarias por empresas privadas".

Das 18 refinarias existentes hoje no país, 14 são da Petrobras (Agência Nacional, 2018b). As outras quatro são: Manguinhos, Univen, Riograndense e Dax Oil, que juntas possuem uma capacidade de refino muito pequena, cerca de $39 \mathrm{mil} \mathrm{bpd,}{ }^{32}$ o que corresponde a apenas $1.8 \%$ do total do país.

Fato é, que as concessões geram um efeito multiplicador na economia do país, em face de que atraem empresas petrolíferas que mantêm o fluxo de investimentos e movimentam a cadeia produtiva do petróleo incentivando e consolidando a indústria nacional que produz bens e serviços para o setor. Atinente a isso, cabe salientar que a indústria do petróleo foi a principal responsável pelo renascimento da indústria naval brasileira (Agência Nacional, 2015).

\section{O ÓLEO DO PRÉ-SAL E OS DESAFIOS DO SÉCULO XXI: 2008-2018}

A chamada província do pré-sal constitui-se no maior campo de petróleo descoberto no mundo desde 2000. ${ }^{33}$ O pré-sal desde então, ganhou cada vez mais destaque na agenda nacional de debates acadêmicos, econômicos, políticos e ambientais não apenas por sua grande reserva de petróleo, mas também por ser uma importante fonte de novos recursos públicos. Além disso, a discussão em torno do pré-sal é ampliada em relação a quanto de crescimento e desenvolvimento será possível gerar com os recursos provindos dessa área, e ainda, quais as possibilidades do Brasil contrair a doença holandesa, ${ }^{34}$ causada pelo aumento da entrada de capital estrangeiro no país que pode levar a uma valorização expressiva da moeda local, provocando uma redução do preço das importações e o consequente encarecimento das exportações, circunstâncias essas que poderiam dificultar as bases do desenvolvimento industrial e econômico do país.

\section{O polígono do pré-sal e o marco regulatório na área}

O pré-sal é um polígono localizado entre os estados do Espírito Santo e Santa Catarina que abrange 200 quilômetros de largura e 800 quilômetros de extensão (ver figura 4). A área total é de 149 mil km² e engloba as bacias sedimentares de Campos e Santos, as quais contêm grandes

${ }^{31} \mathrm{Na}$ atualidade, as principais petroleiras estrangeiras atuando no Brasil são: BP Energy (Inglaterra), Shell (Inglaterra/Holanda), Petrogal Brasil (Portugal), Total (França), cnPsc, cnooc e Sinochem (China), Repsol Sinopec (Espanha/China), Statoil (Noruega), ExxonMobil e Chevron (EUA).

${ }^{32}$ Calculada pela média do período de 2008 a 2017.

33 Anunciado pelo consórcio formado pela Petrobras/British BG Group/Petrogal/Galp em 08 de novembro de 2007.

34 Assim chamada devido a descoberta de gás natural na Holanda em 1960, cuja exportação levou a uma apreciação da taxa de câmbio, o que provocou além de um baixo crescimento do setor industrial, um rápido crescimento do setor serviços e distorção dos preços relativos em relação ao nível de desenvolvimento econômico do país. 
volumes de óleo leve e gás natural num intervalo de rochas que se estende por baixo de uma extensa camada de sal, a qual em algumas áreas da costa pode atingir espessuras de até 2 mil metros. A distância entre a superfície do mar e os reservatórios de petróleo abaixo da camada de sal pode chegar a mais de sete mil metros (Petrobras, em Abreu et al., 2001).

\section{FIGURA 4. POLÍGONO DO PRÉ-SAL}

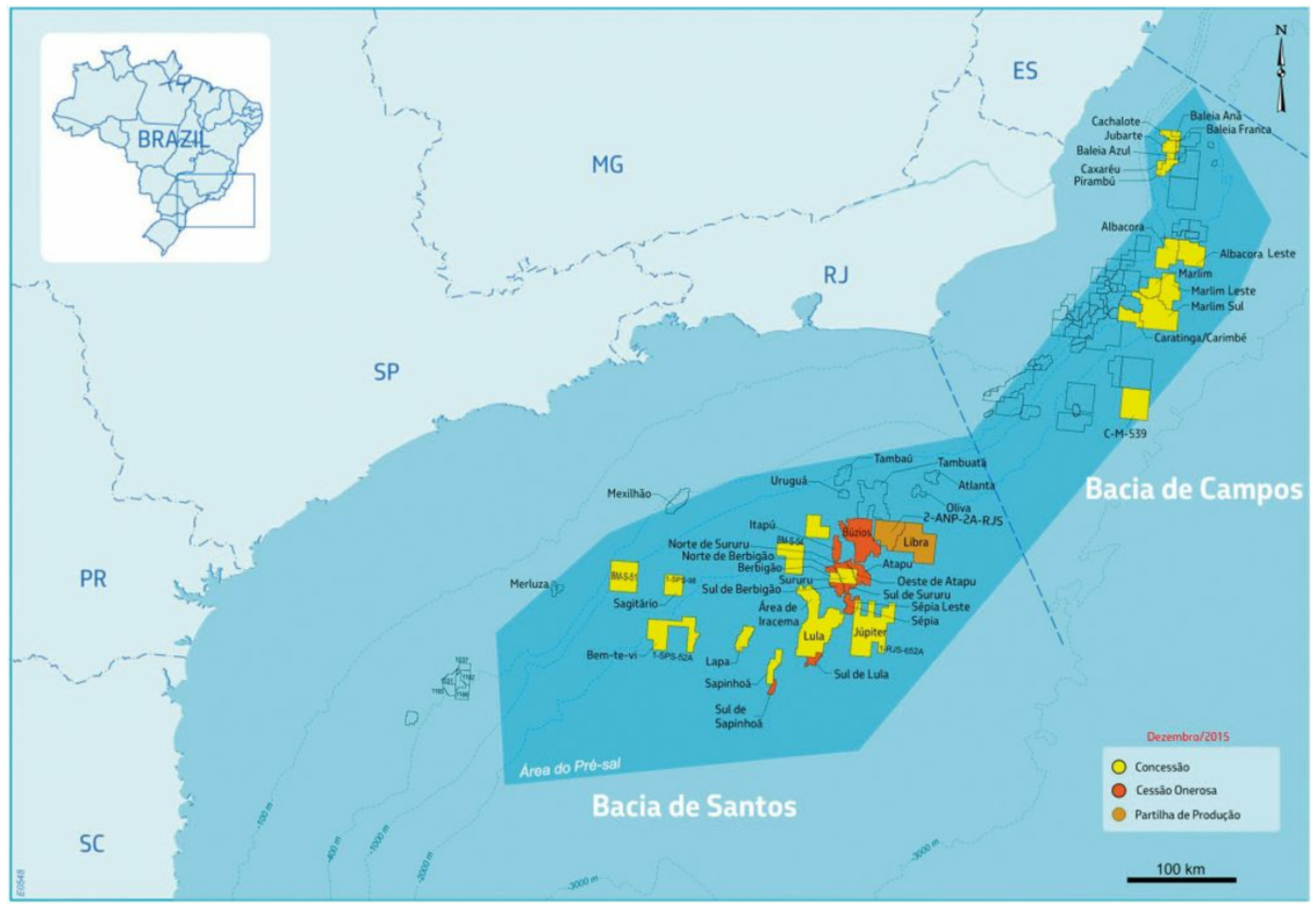

Fonte: TN Petróleo (2017).

A descoberta do pré-sal exacerbou os sentimentos nacionalistas o que gerou uma intensa discussão sobre as regras a serem aplicadas na exploração dessas novas reservas e sobre a distribuição dos recursos gerados (Oddone, 2016). Nesse contexto, diante da grandiosidade das reservas encontradas do pré-sal, o governo brasileiro decidiu proceder alterações no marco regulatório para essa região. Atualmente um conjunto de leis federais publicadas em 2010 norteiam a exploração e produção de petróleo e gás (E\&P) no pré-sal. A lei num. 12.351/2010, também conhecida como Lei da Partilha, ${ }^{35}$ modificou a Lei do Petróleo e instituiu o polígono do pré-sal, determinando que todas as áreas dentro dele, ainda não concedidas, assim como aquelas áreas consideradas estraté-

${ }^{35}$ Lei num. 12.351, 22 de dezembro de 2010, Presidência da República, Casa Civil. Dispõe sobre a exploração e a produção de petróleo, de gás natural e de outros hidrocarbonetos fluidos, sob o regime de partilha de produção, em áreas do pré-sal e em áreas estratégicas; cria o Fundo Social (Fs) e dispõe sobre sua estrutura e fontes de recursos; altera dispositivos da Lei no 9.478, de 6 de agosto de 1997; e dá outras providências. 
gicas e de interesse nacional, só podem ser licitadas no regime de partilha da produção. ${ }^{36}$ Essa lei também obrigava a Petrobras a ser a operadora com um mínimo de 30\% de todos os consórcios de exploração no blocos licitados dentro do polígono do pré-sal. Além disso, a lei estabeleceu o Fundo Social, submetido à Presidência da República, cuja finalidade é constituir uma fonte de recursos para o desenvolvimento social e regional.

A lei num 12.304/2010 criou a Pré-Sal Petróleo s. A., que atua como representante da União no regime de partilha de produção, tendo em vista que a Petrobras, por ser uma empresa de capital misto, não pode exercer tal função. ${ }^{37}$ Já, a lei num. 12.276/2010 autorizou a União a capitalizar a Petrobras por meio de uma cessão onerosa que deu o direito de a Petrobras extrair sem licitação até o limite de cinco bilhões bpd de óleo equivalente (petróleo + gás natural) em seis áreas definitivas do pré-sal na Bacia de Santos que não estão sob o modelo de concessão ${ }^{38}$ (ver figura 5). Portanto, desde o advento do pré-sal, existem no Brasil três sistemas que regulam as atividades de exploração e de produção de petróleo e gás natural: concessão, partilha e cessão onerosa.

Segundo estimativas da ANP, os volumes de óleo adicionais na área de cessão onerosa são entre 9.8 e 15.2 bilhões de barris de óleo equivalente (boe ${ }^{40}$ (Petrobras, 2014). Como esse óleo excedente pertence à União, o governo quer licitá-los, mas, para tanto, há que se aprovar o Projeto de Lei num. 8.939/2017, ${ }^{41}$ que altera a Lei Federal num. 12.276/2010, para permitir à Petrobras a transferência parcial a terceiros de até $70 \%$ dos campos da cessão onerosa. Nota-se que, a cessão onerosa incluindo os volumes excedentes é de extrema importância para o setor petrolífero no país (ver figura 6). Pode-se observar que, a área responderá por cerca de $35 \%$ do total da produção de petróleo em 2027. Já os contratos de partilha da produção e os contratos de concessão contribuirão respectivamente com 18\% e 47\% da produção nacional (Ministério de Minas e Energia, 2018).

Uma breve retrospectiva da E\&P de óleo e gás no pré-sal permite uma visão geral da importância dessa reserva petrolífera. A produção diária de petróleo no pré-sal realizada pela Petrobras em parceria com companhias internacionais de petróleo passou de aproximadamente $41 \mathrm{mil} \mathrm{bpd} \mathrm{em}$ 2010 para mais de 1.5 milhão bpd em 2018, um crescimento expressivo. Outro dado que mostra a alta produtividade do pré-sal é a quantidade de poços produtores em relação ao volume de produção. ${ }^{42}$ Diante disso, o pré-sal permitirá ao país ser autossuficiente e tornar-se um player relevante no mercado internacional. Há de se ressaltar também a qualidade dos hidrocarbonetos

${ }^{36}$ Do total de óleo produzido pela empresa contratada, são descontados todos os custos relativos à exploração e produção (custo em óleo), para se apurar o volume de petróleo e/ou gás restante (excedente em óleo) rateado entre União e a petroleira, que por sua vez, pagará royalties relativos à sua parcela da produção. Nesse modelo, vence a petroleira que oferecer à União a maior parcela do excedente em óleo.

${ }^{37}$ Lei num. 12.304, 2 de agosto de 2010, Presidência da República, Casa Civil. Autoriza o Poder Executivo a criar a empresa pública denominada Empresa Brasileira de Administração de Petróleo e Gás Natural S.A. - Pré-Sal Petróleo S. A. (PPSA) e dá outras providências.

${ }^{38}$ Lei num. 12.276, 30 de junho de 2010, Presidência da República, Casa Civil. Autoriza a União a ceder onerosamente à Petróleo Brasileiro s. A. (Petrobras) o exercício das atividades de pesquisa e lavra de petróleo, de gás natural e de outros hidrocarbonetos fluidos de que trata o inciso I do art. 177 da Constituição Federal, e dá outras providências.

${ }^{40} \mathrm{O}$ gás natural normalmente é encontrado junto com o petróleo, mas, a proporção de óleo e gás varia de poço para poço, de forma que qualquer um pode ser o produto principal de um campo. Aproximadamente $170 \mathrm{~m}^{3} \mathrm{de} \mathrm{gás}^{2}$ natural são considerados equivalentes a um barril de petróleo.

41 Aprovado na Câmara dos Deputados em julho de 2018, a proposta agora tramita no Senado Federal.

42 A produção do pré-sal no momento presente vem de três regiões: o Cluster de Lula na Bacia de Santos, a porção do Rio de Janeiro da Bacia de Campos e o Parque das Baleias na porção do Espírito Santo, também na Bacia de Campos. 


\section{FIGURA 5. ÁREA DE GESSÃO ONEROSA E POLÍGONO DO PRÉ-SAL}

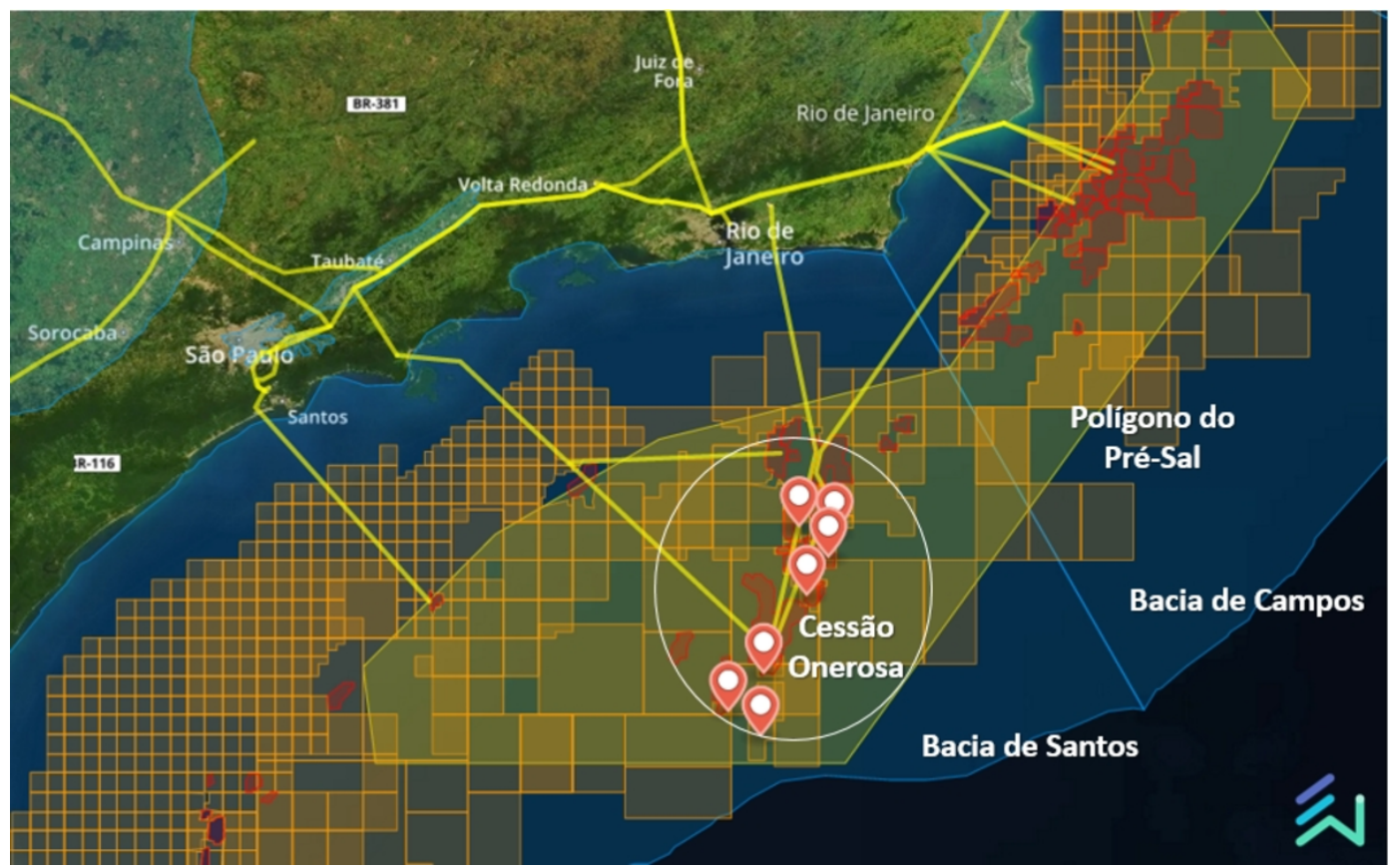

Fonte: Nota: Blocos concedidos: Franco, Florim, Nordeste de Tupi, Sul de Tupi, Sul de Guará, Entorno de Iara e Peroba. $^{39}$

Fonte: Instituto de Estudos Estratégicos de Petróleo, Gás Natural e Biocombustíveis Zé Eduardo Dutra (2018).

do pré-sal que são leves e possuem maior valor de mercado, contrastando com cerca de $65 \%$ da produção nacional de óleo médio e pesado. Relevante ainda citar, que o custo de extração do barril na área do pré-sal caiu de US\$ 14 o barril em 2014 para menos de US\$ 7 em 2017 (Agência Nacional, 2018c; Petrobras, 2018). Não obstante, apesar de ainda não se saber o volume total de hidrocarbonetos, admite-se que a província do pré-sal contenha volumes recuperáveis que podem ultrapassar 40 bilhões de barris (Oddone, 2016).

Recessão econômica, queda de investimentos no setor e a crise na Petrobras

A exploração e produção de petróleo e gás no Brasil atravessou um período crítico entre 2008 e 2012 devido a não ocorrência de os leilões de áreas para exploração por vários fatores, tais como: a) intensas discussões no meio político, econômico e jurídico sobre as regras para a exploração do pré-sal e a distribuição dos recursos gerados; b) exigência governamental de alto índice de conteúdo local no fornecimento de equipamentos para a indústria de petróleo; c) concentração da E\&P na Petrobras no polígono do pré-sal; e d) queda do preço do petróleo. Em vista disso, em uma década de pré-sal apenas uma área foi licitada nesse período, a de Libra. Esses cinco anos de drástica queda na E\&P traz preocupações no futuro, principalmente, com respeito à reposição das reservas que estão sendo depletadas pelo ritmo atual de produção, levando-se em conta que a média histórica do tempo decorrido entre a assinatura do contrato para a realização do investimento e a extração do primeiro óleo é de oito anos offshore e seis anos em terra (Oddone, 2018). 


\section{FIGURA 6. PREVISÃO DE PRODUÇÃO DE PETRÓLEO NACIONAL POR TIPO DE CONTRATO}

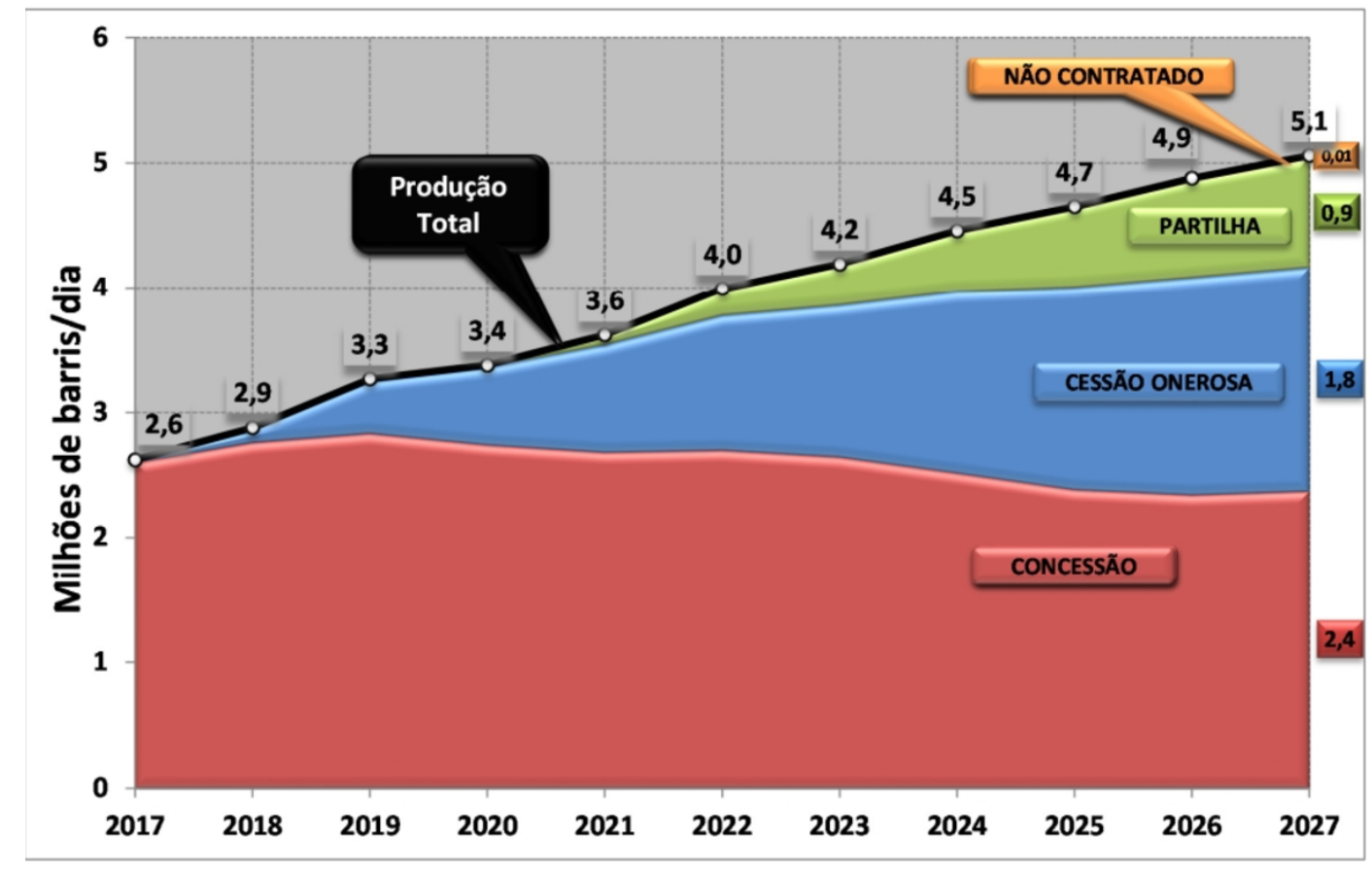

Fonte: Ministério de Minas e Energia (2018).

Importante também destacar, que em decorrência da descoberta dos campos do pé-sal, a Petrobras desenvolveu um ambicioso plano de investimentos nas áreas de exploração e produção de petróleo bruto e seus derivados, principalmente para expansão da capacidade de refino. ${ }^{43}$ Entre 2005 e 2009 o volume de investimentos multiplicou-se por 3.5, alcançando em valores atuais 48.8 bilhões de dólares em 2013. Porém, houve um completo descolamento entre a ampliação do montante dos investimentos da companhia e o seu nível de produção de petróleo e gás natural, ocorrendo inclusive, uma inflexão negativa da produção que chegou até a cair no início da década de 2010 (Furtado, 2019).

Não obstante, a Petrobras foi atingida por uma série de acontecimentos que a levaram a sofrer uma severa crise. Destacam-se nesse contexto, a alta do preço internacional do petróleo entre 2011 e 2013, que coincidiu com o aumento do consumo de derivados de petróleo no Brasil. Nessa ocasião, as refinarias da Petrobras não conseguiram acompanhar a demanda, fazendo com que a Petrobras importasse, sobretudo, gasolina e óleo diesel. Além disso, o governo brasileiro, que é o controlador acionário da Petrobras interferiu na política de preços da companhia, fazendo com que a alta dos preços do petróleo não fosse repassada para os preços da gasolina e do diesel, o que impôs prejuízos milionários à companhia. Nesse sentido, Furtado $(2019$, p. 167) cita que "O

${ }^{43}$ Foram aprovados investimentos para quatro novas refinarias de petróleo. À época, acreditava-se que a produção de petróleo ultrapassaria significativamente o consumo interno. Assim, o petróleo deveria ser processado para agregar valor às exportações (Furtado, 2019). 
valor da dívida líquida foi multiplicado em mais de 7 vezes entre 2008 e 2015 , enquanto o lucro bruto (Ebitda ${ }^{44}$ da empresa se manteve praticamente estável. O indicador do endividamento sobre o lucro, que era inferior a 1 em 2008, ultrapassou o valor de 5 em 2015".

Em meio a esses acontecimentos, o segundo mandato do governo Dilma Rousseff (20152016) foi marcado por um acentuado intervencionismo do Estado na economia do país e por um aumento dos gastos públicos, o que levou a um desequilíbrio fiscal nas contas do governo. Essa sucessão de fatores fez com que o PIB do país sofresse uma queda acumulada de $8 \%$ nos anos de 2015-2016, culminando na pior recessão econômica do Brasil.

Do mesmo modo, se faz importante destacar, as questões políticas envolvendo corrupção interna que abalaram seriamente a Petrobras, que está sendo investigada criminalmente no âmbito da operação Lava-Jato realizada pela Polícia Federal do Brasil, a maior investigação sobre corrupção já conduzida no Brasil, cujo início ocorreu em 2014. A companhia vem enfrentando, talvez, o maior desafio da sua história, pois a cobrança de propina institucionalizada na empresa pelos partidos da base política entre 2003-2016, ${ }^{45}$ e que atingiu todas as áreas da companhia, tais como, construção de refinarias, importação de petróleo, contratação de prestadores de serviços, entre outras.

Essa série de eventos, além de causar danos financeiros e institucionais, acarretou ainda o rebaixamento do rating da empresa, que culminou com a queda drástica no preço de suas ações no Brasil e no exterior, visto que a Petrobras usa também o mercado internacional para se financiar. ${ }^{46}$ Em agosto de 2014, uma ação da companhia na Bolsa de Nova Iorque custava US\$ 19.57; em janeiro de 2016, o valor era US\$ 3.03, uma desvalorização de quase 85\% (Almeida, 2018). Além disso, a Petrobras enfrentou processos judiciais no Brasil e no exterior, ${ }^{47}$ e em abril de 2015 divulgou um balanço em que admitia ter perdido $\mathrm{R} \$ 51$ bilhões, sendo $\mathrm{R} \$ 6.2$ bilhões devido à corrupção. ${ }^{48}$ Para enfrentar a pior crise de sua história, a Petrobras vem reduzindo de tamanho e focando áreas estratégicas. O investimento da petroleira, segundo Furtado (2019), foi concentrado em investimentos no upstream, ${ }^{49}$ cuja participação no total de investimentos estava em $51 \%$ em 2012, e subiu para $85.1 \%$ em 2016.

Atualmente, ${ }^{50}$ a Petrobras regula o preço dos combustíveis de acordo com critérios de mercado internacional, o que foi positivo para aumentar o seu valor de mercado e focando seus investimentos na área de E\&P no Brasil, com ênfase em águas profundas, segmento em que detém reconhecida competência. Nas demais áreas de negócios, a companhia está se reestruturando e realizando desinvestimentos. Atualmente a Petrobras enfrenta um aumento da concorrência, tanto no mercado

${ }^{44}$ Lucros antes de Juros, Impostos, Depreciação e Amortização.

${ }^{45}$ Período que abrangeu os governos dos então presidentes Lula da Silva e Dilma Rousseff.

${ }^{46}$ Cf. Petrobras 2018, atualmente a Petrobras negocia ações nas bolsas de São Paulo (B3), Bolsa de Nova Iorque (NYsE), no mercado de ações de empresas latino-americanas na Espanha (Latibex) e na Bolsa de Comércio de Buenos Aires (BCBA).

47 Cf. Petrobras (2018), a companhia foi processada nos EuA por investidores que adquiriram seus títulos, chamados American Depositary Receipts (ADR), que alegaram que a corrupção da Petrobras inflou artificialmente a cotação desses papéis, culminando em um enorme declínio no valor após o escândalo se tornar público. Em setembro de 2018, a Petrobras fechou um acordo com as autoridades norte-americanas no valor de US\$ 853 milhões para encerrar as investigações.

${ }^{48}$ Cf. Petrobras (2018), o total de recursos devolvidos para a Petrobras por meio de acordos de colaboração com pessoas físicas e jurídicas no âmbito da operação, até setembro de 2018 foi de R\$ 2.5 bilhões.

${ }^{49}$ Setor de exploração e produção.

${ }^{50}$ Desde 15/10/2016. 
doméstico, apesar de manter uma posição dominante, como no mercado global, o que a levou a aprimorar de forma constante sua estrutura e serviços e a melhorar seu desempenho financeiro e operacional.

Diante do exposto, pode-se afirmar que as consequências da crise da Petrobras para o conjunto da economia brasileira são muito relevantes. Furtado (2019), cita que, tomando-se por base a importância relativa do investimento realizado pela indústria petrolífera para o conjunto dos investimentos do país [. . .] o setor do petróleo e gás natural foi responsável por $54.1 \%$ da queda do investimento industrial e por $42.9 \%$ do investimento total do país no período $2013-2017$ (p. 172).

\section{A retomada de investimentos no setor petrolífero brasileiro e o mercado de gás natural}

O setor petrolífero no Brasil está em franca retomada de investimentos iniciada com uma importante alteração institucional, a promulgação da Lei Federal num. 13.365/2016, que retirou a Petrobras da operação única pelo regime de partilha de produção em áreas do pré-sal. ${ }^{51}$ Além disso, outras importantes medidas que desencadearam um novo entusiasmo no setor de óleo e gás no Brasil foram a flexibilização de conteúdo local para contratos até a $13^{\text {a }}$ Rodada de Licitações, a extensão do Repetro ${ }^{52}$ e o estabelecimento de um calendário de 10 rodadas de licitação entre 2017 e 2019 , sendo quatro delas no pré-sal. Diante disso, alguns números são relevantes (Oddone, 2018), haja vista que entre 2016 e 2018 foram assinados 79 contratos de exploração e produção, tanto na concessão quanto na partilha que resultaram em 7 bilhões em bônus de assinatura. A projeção para 2030 é que o Brasil esteja produzindo 7.5 milhões bpd, praticamente o triplo do valor registrado em 2017, o que colocará o país entre os cinco maiores produtores do mundo.

Portanto, percebe-se que não fazia sentido manter a Petrobras como operadora compulsória no pré-sal. ${ }^{53}$ A esse respeito, é oportuno lembrar que a companhia deve atuar em conformidade com a Constituição: ${ }^{54}$ "A Petrobras não é prestadora de serviço público. Não pode ser concebida como delegada da União. Explora atividade econômica em sentido estrito, sujeitando-se ao regime jurídico das empresas privadas [inclusive quanto às obrigações trabalhistas e tributária]" (Supremo Tribunal Federal, 2005, para. 14). Também, é importante mencionar que a União poderá contratar empresas estatais ou privadas a realização das atividades de pesquisa e lavra das jazidas de petróleo e gás natural e outros hidrocarbonetos fluidos. ${ }^{55}$ Ou seja, a Petrobras deve atuar em regime de competição com empresas privadas nos processos licitatórios. Nesse contexto, cabe lembrar mais um ponto favorável apontado por Humphreys, Sachs e Stiglitz (2007), que quando há aumento do nível de concorrência entre as companhias os riscos de corrupção envolvendo as relações entre o público e o privado se reduz.

${ }^{51}$ Lei num. 13.365, 29 de novembro de 2016, Presidência da República, Casa Civil. Altera a Lei no 12.351, de 22 de dezembro de 2010, para facultar à Petrobras o direito de preferência para atuar como operador e possuir participação mínima de 30\% nos consórcios formados para exploração de blocos licitados no regime de partilha de produção.

${ }^{52}$ Em 18/08/2017 foi publicado no Diário Oficial da União, a prorrogação concedida pelo governo federal até 2040 de regime aduaneiro especial permitindo a suspensão do pagamento dos tributos federais, para exportação e importação de bens utilizados nas atividades de pesquisa e de lavra das jazidas de petróleo e gás natural.

${ }^{53}$ A exploração direta de atividade econômica pelo Estado só será permitida quando necessária aos imperativos da segurança nacional ou a relevante interesse coletivo (Supremo Tribunal Federal, 2005, [n. p]).

54 Artigo 173, inciso II, parágrafo 1.

55 Brasil, 2017, artigo 177, parágrafo 1. 
Quando a Petrobras foi fundada na década de 1950, o Brasil era um país predominantemente agrário. Apenas 36\% da população vivia em cidades e o setor industrial respondia por cerca de $10 \%$ do PIB. Hoje em dia, setenta anos depois, o Brasil se tornou um país urbano, com um grande parque industrial. No entanto, o setor de petróleo e gás continua sendo dominado pela Petrobras. O modelo que se desenvolveu no país, assemelha-se ao adotado em alguns países da região, como a Argentina, onde, entretanto, as petroleiras privadas possuem mais participação na exploração, produção e refino de petróleo com a empresa governamental YPF (Oddone, 2016).

Nesse contexto, as evidências teóricas e empíricas da literatura econômica em diversos setores industriais, indicam que uma maior competição estimula o investimento, que por sua vez tende a aumentar a inovação permitindo a operação com custos mais competitivos. O impacto macroeconômico dos dispêndios CAPEX ${ }^{56}$ para se produzir no âmbito do pré-sal, indica que a cada R\$ 1 bilhão gasto, há um aumento na produção da economia nacional em cerca de R\$ 2.45 bilhões, já computados os efeitos diretos, indiretos e induzidos pelo aumento da renda das pessoas, além da capacidade de gerar 33570 postos de trabalho nos diversos setores da economia (Instituto Brasileiro de Economia, 2010).

Relevante também mencionar que a indústria do gás natural ainda é incipiente no Brasil. Atualmente a Petrobras detém 77\% da produção de gás, 100\% da importação, além de controlar a rede de gasodutos e a comercialização. Portanto, a companhia atua praticamente como monopolista do setor. Essa falta de competição e de oferta a preços atraentes dificultou o uso do gás no setor industrial brasileiro, haja vista, que o Brasil tem apenas $9.4 \mathrm{mil} \mathrm{km}$ de gasodutos de transporte. Além disso, o gás na matriz energética brasileira representa apenas 13\%. A título de comparação, a Argentina possui 28.9 mil km de gasodutos e a participação do gás chega a $52 \%$ na matriz energética. Nesse contexto, o preço do gás para o consumidor industrial no Brasil está nos patamares dos mais caros da Europa. ${ }^{57}$ Isto posto, percebe-se que o modelo atual não é conveniente para o país (Ministério de Minas e Energia, 2019; Oddone, 2019).

Com intuito de promover a atração de novos agentes para o mercado, foi publicada a Lei do Gás (Lei num. 11.909/2009), sem, contudo, atingir os objetivos propostos. Em 2015 a Petrobras iniciou processo de redução de sua participação no mercado de gás natural por meio de desinvestimentos de alguns ativos, promovendo a oportunidade para revisão do marco legal e regulatório do setor de gás (Ministério de Minas e Energia, 2019; Oddone, 2019). Em 2019, o Conselho Nacional de Política Energética (GNPE) aprovou a Resolução num. 16/2019 que "[. . .] estabelece diretrizes e aperfeiçoamentos de políticas energéticas voltadas à promoção da livre concorrência no mercado de gás natural, definindo como deve ser a transição para um mercado concorrencial [. . .]" (Ministério de Minas e Energia, 2019, para. 11).

Com o esperado aumento da produção de petróleo oriunda do pré-sal, haverá maior produção de gás associado, o que por conseguinte, aumentará a oferta de gás no mercado doméstico.

${ }^{56}$ Expressão inglesa capital expenditure, o CAPEX é frequentemente utilizado para realizar novos projetos ou investimentos ou ainda aumentar o escopo de operações.

${ }^{57}$ US\$ 10.8/MMBTU em 2018. Cf. http://www.mme.gov.br/web/guest/conselhos-e-comites/cmgn/novo-mercadode-gas 
Diante disso, o governo brasileiro lançou em 2019 o Programa Novo Mercado de Gás, ${ }^{58}$ o qual promove a concorrência e a desverticalização do setor, atraindo múltiplos players para esse mercado, o que certamente estimulará a utilização do gás na geração termelétrica em substituição ao óleo combustível e o diesel, reduzindo o custo e tornando a geração mais limpa.

Um panorama da evolução do marco regulatório e do ambiente econômico e político no Brasil pode ser observada na figura 7 .

\section{FIGURA 7. HISTÓRIA POLÍTICA RECENTE DO SETOR DE PETRÓLEO E GÁS NO BRASIL}

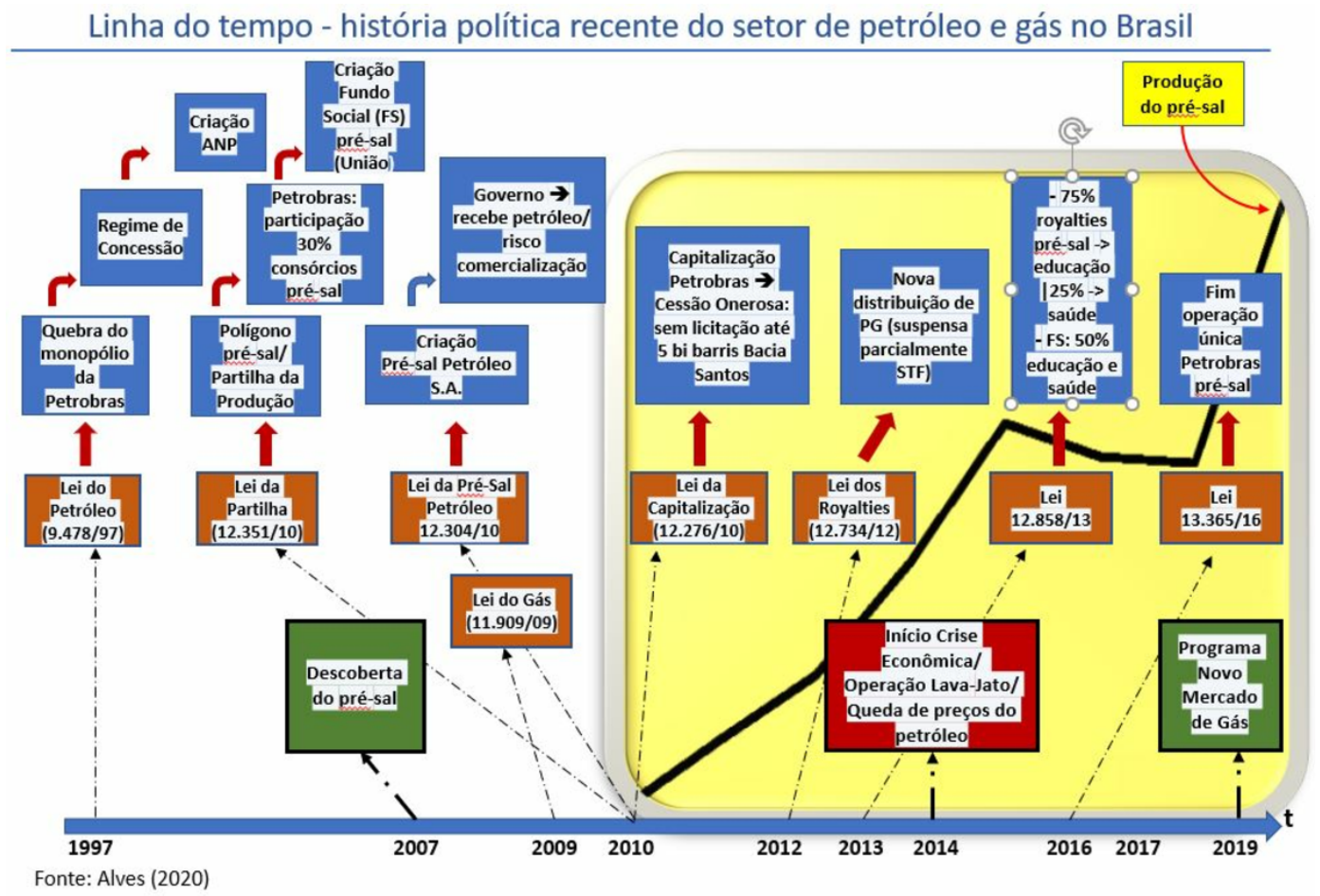

Fonte: Alves (2020).

Essa evolução e modernização no setor petrolífero brasileiro certamente refletirá positivamente ao longo da cadeia produtiva do petróleo e gás, tanto a montante como a jusante, acarretando benefícios tanto para o cidadão, quanto para o setor industrial aumentando sua produtividade e competitividade.

${ }^{58}$ Lançado em 23 de julho de 2019. Foi também criado o Comitê de Monitoramento da Abertura do Mercado de Gás Natural (CMGN), instituído por meio do Decreto num. 9.934/2019. Esse programa conta com a participação do Ministério de Minas e Energia (MME), do Ministério da Economia (me), da ANP, da Empresa de Planejamento Energético (EPE) e do Conselho Administrativo de Defesa Econômica (CADE) (Ministério de Minas e Energia, 2019). 


\section{Conclusões}

Ficou evidenciado na análise dos diversos períodos de transformações no marco regulatório da indústria de petróleo e gás natural no Brasil ao longo do século Xx e XI, que o setor foi marcado por uma série de instabilidades de ordem política e institucional, entre os quais destaca-se a conjunção de três episódios recentes marcados pela grave recessão econômica de 2015 e 2016 motivada por erros de política monetária e fiscal e por uma maior intervenção na economia, a derrocada dos preços do petróleo no mercado internacional e a Operação Lava-Jato que atingiu a maior empresa do país, a Petrobras. Esses fatos impactaram diretamente nas decisões dos diversos stakeholders quanto aos investimentos em pesquisa e desenvolvimento na exploração de novas áreas de exploração de petróleo.

Por outro lado, as recentes medidas regulatórias a partir de 2018 alavancaram os investimentos na atividade exploratória que são a mola propulsora da indústria petrolífera, e, que consequentemente, influenciam toda a cadeia produtiva tanto a montante como a jusante, além de refletirem diretamente no volume de participações governamentais. Nesse panorama, o setor petrolífero no Brasil ainda tem muito a crescer, pois, apesar das grandes dimensões, menos de $5 \%$ da área sedimentar do país estão contratados. O número de poços perfurados no país é muito pequeno -cerca de 30 mil- metade do que a Argentina perfurou, e apenas uma fração dos mais de 4 milhões de poços perfurados nos EuA. Adicionalmente, ainda existem duas bacias sedimentares inteiras (Pernambuco-Paraíba e Madre de Dios) sem um único poço perfurado (Agência Nacional, 2018a).

Também é pertinente sublinhar que no modelo de partilha, entre 70\% e 75\% da renda petroleira fica com a União. ${ }^{59}$ Por conseguinte, se a extração e produção de petróleo e gás no Brasil for realizada pela Petrobras ou por quaisquer outras petroleiras de capital estrangeiro, a renda auferida por essa atividade econômica beneficiará a sociedade como um todo, em termos de geração de emprego e renda promovida pela cadeia produtiva upstream, midstream e downstream do petróleo. ${ }^{60}$ Portanto, não é razoável que um setor econômico crucial como o de óleo e gás dependa da rentabilidade, liquidez, endividamento e geração de caixa, em outras palavras, da condição econômico-financeira da Petrobras.

Outrossim, o mundo estar caminhando para uma economia de baixo carbono, o petróleo ainda será o principal componente da matriz energética mundial respondendo por $53 \%$ da oferta primária de energia até 2040 (BP, 2018). Além disso, o aumento significativo da oferta de petróleo não convencional no mundo, como o recente boom do shale oil nos EUA, impactou negativamente o preço da commodity. Por isso, o Brasil precisa extrair o quanto antes a riqueza petrolífera existente principalmente offshore, visto que a maior parte das suas reservas estão no mar.

Em que pese os diversos percalços transpostos pelo Brasil nas diversas áreas ao longo de sua história recente, a produção nacional de hidrocarbonetos aumentou, e o país se tornou desde 2016 o maior produtor de petróleo da América Latina superando os principais países exportadores de petróleo da região, Venezuela e México (BP, 2018). Esse sucesso é, em grande parte, resultado

${ }^{59}$ Informações detalhadas podem ser consultadas em Quintans (2016) e Agência Nacional (2017).

${ }^{60}$ Upstream é o setor de exploração e produção; midstream inclui processamento, armazenamento, transporte e comercialização de petróleo, gás natural e outros hidrocarbonetos fluídos; downstream são refinarias, indústrias petroquímicas, distribuição de produtos de petróleo, varejo e empresas de distribuição de gás natural que fornecem milhares de produtos. 
da liberalização da indústria petrolífera na década de 1990, aliado ao fato de que, conforme Monaldi (2010), o Brasil não nacionalizou e nem quebrou contratos a exemplo de Argentina, Bolívia, Equador e Venezuela.

Diante do exposto, conclui-se que o Brasil está muito próximo de consolidar seu setor petrolífero como pólo de atração de grandes investimentos que poderão contribuir para acelerar as mudanças estruturais necessárias por meio das reformas já aprovadas e as que estão sendo debatidas no Congresso Nacional. Além disso, o Brasil tem melhorado suas contas públicas e reduzido o peso do Estado na economia. Não obstante, é um país que tem por tradição o respeito aos contratos, o que é fundamental para atrair investimentos produtivos de longo prazo.

\section{LISTA DE REFERÊNCIAS}

Abreu, A. A. de, Beloch, I., Lattman-Weltman, F. e Lamarão, S. (2001). Dicionário históricobiográfico brasileiro, pós-1930 (2. ed. rev. e atualizada). Brasil: Fundação Getúlio Vargas/Centro de Pesquisa e Documentação de História Contemporânea do Brasil. Recuperado de http://ww w.fgv.br/cpdoc/acervo/dicionarios/verbete-biografico/jose-bento-monteiro-lobato

Abreu, M. de P. (Org.). (1990). A Ordem do progresso: Cem anos de política econômica republicana, 1889-1989. Rio de Janeiro: Editora Campus.

Agência Nacional do Petróleo, Gás Natural e Biocombustíveis (2015). Petróleo e Estado. Brasil: Autor. Recuperado de http://www.anp.gov.br/images/publicacoes/livros_e_revistas/livro-petrol eo-e-estado-ANP.pdf

Agência Nacional do Petróleo, Gás Natural e Biocombustíveis (2017). Lei do petróleo completa 20 anos. Recuperado de http://www.anp.gov.br/noticias/3928-lei-do-petroleo-completa-20anos

Agência Nacional do Petróleo, Gás Natural e Biocombustíveis (2018a). Anuário estatístico brasileiro do petróleo, gás natural e biocombustíveis 2018. Brasil: Autor. Recuperado de http://www.anp.gov. br/images/publicacoes/anuario-estatistico/2018/anuario_2018.pdf

Agência Nacional do Petróleo, Gás Natural e Biocombustíveis. (2018b). Oportunidades no setor de petróleo e gás natural no Brasil-Rodadas de licitações 2017-2019. Autor. Recuperado de http://www.anp.gov.br/images/publicacoes/Livreto_Upstream_2018-P.pdf

Agência Nacional do Petróleo, Gás Natural e Biocombustíveis (2018c). Pré-sal já responde por $54 \%$ da produção brasileira de petróleo e gás. Recuperado de http://www.anp.gov.br/noticias/a np-e-p/4454-pre-sal-ja-responde-por-54-da-producao-brasileira-de-petroleo-e-gas

Agência Petrobras. (2006). Bahia deu berço e escola ao petróleo brasileiro. Recuperado de http://www.agenciapetrobras.com.br/Materia/ExibirMateria?p_materia=1304

Agência Petrobras. (2018). Exposição Petrobras em 60 momentos. Brasil: Autor.

Almeida, C. (2018). O bilionário acordo da Petrobras nos EUA acontecerá no Brasil? Recuperado de https://exame.com/mercados/o-bilionario-acordo-da-petrobras-nos-eua-acontecera-nobrasil/

Alves, J. A. B. (2020). Impactos dos Royalties do Pré-Sal no Pré-Sal no Desenvolvimento dos Municípios Costeiros do Sudeste Brasileiro (Tese de Doutorado). Universidade do Vale do Itajaí, Brasil.

Andrade, R. B. de. (2011). A regulação do pós-lavra no direito minerário brasileiro. Revista de Direito, Estado e Recursos Naturais, 1(1), 79-106.

Andrade, R. O. (2018). Conhecimento do fundo da terra. Pesquisa Fapesp, 19, 92-94. 
Bagnoli, V. (2011). Direito econômico (5a. ed.). Brasil: Atlas.

Barbosa, A. R. (2004). A natureza jurídica da concessão para exploração de petróleo e gás natural一 Jus.com.br |Jus Navigandi. Revista Jus Navigandi, 9(389). Recuperado de https://jus.com.br/ar tigos/5521/a-natureza-juridica-da-concessao-para-exploracao-de-petroleo-e-gas-natural

Bastos, I. P. (2017). Bacia do Recôncavo-Sumário Geológico e Setores em Oferta. Brasil: Agência Nacional do Petróleo. Recuperado de http://rodadas.anp.gov.br/arquivos/Round14/Mapas/sumar ios/Sumario_Geologico_R14_Reconcavo.pdf

Beesley, M. E. (1997). Privatization, regulation and deregulation (2a. ed.). London: Routledge.

BP (2018). BP Statistical Review of World Energy 2018 (No 67). BP.

Brasil (2017). Constituição da República Federativa do Brasil: Texto constitucional promulgado em 5 de outubro de 1988, com as alterações determinadas pelas Emendas Constitucionais de Revisão nos 1 a 6/94, pelas Emendas Constitucionais nos 1/92 a 99/2017 e pelo Decreto Legislativo no 186/2008. Brasilia: Senado Federal, Coordenação de Edições Técnicas.

Bucheli, M. (2010). Major trends in the historiography of the latin american oil industry. Business History Review, 84(2), 339-362. DOI: 10.1017/S0007680500002646

Câmara dos Deputados. (2008). Década de 70. Recuperado de https://www2.camara.leg.br/ativi dade-legislativa/plenario/discursos/escrevendohistoria/visitantes/panorama-das-decadas/co py_of_decada-de-70

Carnio, G. O. (1997). Ação e Pensamento de Monteiro Lobato [Monografía]. Brasil: Universidade Estadual de Campinas. Recuperado de http://www.bibliotecadigital.unicamp.br/document/?dow $\mathrm{n}=000296027$

Caselli, B. C. (2011). O pré-sal e as mudanças da regulação da indústria do petróleo e gás natural no Brasil: Uma visão institucional. Revista Brasileira de Direito Público, 9(35).

Cortez, L. A. B., Brito, C. H., Souza, G., Cantarella, H., Sluys, M. V. e Maciel, R. (2016). Universidades e empresas: 40 anos de ciência e tecnologia para o etanol brasileiro. São Paulo: Blucher. Recuperado de https://openaccess.blucher.com.br/article-list/proalcool-universidadese-empresas-40-anos-de-ciencia-e-tecnologia-para-o-etanol-brasileiro-310/list\#undefined

Dias, J. L. M. e Quaglino, M. A. (1993). A questão do petróleo no Brasil: Uma história da Petrobrás. Brasil: Fundação Getúlio Vargas.

Furtado, A. T. (2019). Indústria do Petróleo e Gás Natural: Uma vocação desperdiçada. Cadernos do Desenvolvimento, 14(24), 155-175.

Humphreys, M., Sachs, J. e Stiglitz, J. (2007). Future Directions for the Management of Natural Resources. In Escaping the resource curse (pp. 322-348). Nova York: Columbia University Press. Recuperado de http://policydialogue.org/files/publications/Ch12.pdf

Instituto Brasileiro de Economia (2010). Pré-Sal: Potenciais Efeitos do Operador Único. Brasil: Autor/FGV.

Instituto Brasileiro de Geografia e Estatística (1990). Estatísticas históricas do Brasil: Séries econômicas, demográficas e sociais de 1550 a 1988 (2da. ed.). Brasil: Autor.

Instituto de Estudos Estratégicos de Petróleo, Gás Natural e Biocombustíveis Zé Eduardo Dutra (2018, junho 25). Mudança na cessão onerosa e a entrega do pré-sal. INEEP. Recuperado de https://ineep.org.br/a-mudanca-no-regime-de-cessao-onerosa-e-a-entrega-do-pre-sal/

Joskow, P. L. e Noll, R. C. (1981). Regulation in Theory and Practice: An overview. Em G. Fromm (Org.), Studies in public regulation. Cambridge: MIT Press.

Lucchesi, C. F. (1998). Petróleo. Estudos Avançados, 12(33), 17-40. 
Melo, A. de. (1969). Alagoas, Petróleo e Petrobrás: A Mistica do Petróleo não se Esgotou Com a sua Descoberta. Brasil: Serviços Gráficos Gazeta de Alagoas.

Melo, H. P. de e Oliveira, A. de (2015). Café e Petróleo: Um Paralelo Histórico. Cadernos do Desenvolvimento Fluminense, (7), 91-104. DOI: 10.12957/cdf.2015.19720

Ministério de Minas e Energia (2018). Plano Decenal de Expansão de Energia 2027. Brasil: Autor.

Ministério de Minas e Energia (2019). Novo Mercado de Gás. Brasil: Autor.

Monaldi, F. (2010). A Economia Política do Petróleo e do Gás na América Latina (Working Paper num. 9). Recuperado de ttp://www.plataformademocratica.org/Arquivos/A\%20Economia\%20Poli tica\%20do\%20Petroleo\%20e\%20do\%20Gas\%20na\%20America\%20Latina.pdf

Monaldi, F. (2015). Latin America's Oil and Gas: After the Boom, a New. Recuperado de http://reposi torio.flacsoandes.edu.ec/handle/10469/8262

Morais, J. M. de (2013). Petróleo em águas profundas: Uma história tecnológica da PETROBRAS na exploração e produção offshore. Brasília: Ipea.

Moreira, R. L. e Lamarão, S. T. N. (2003). A campanha do petróleo e a criação da Petrobras. Brasil: CPDOC/FGV.

Neves, A. (1948). Monteiro Lobato. Fundamentos. Revista de cultura moderna, 2(4-5).

Oddone, D. (2016). Óleo E̊ Gás no Brasil: Uma oportunidade histórica? Washington, DC: Atlantic Council.

Oddone, D. (2017). O setor de petróleo e gás no Brasil. ANP. Recuperado de http://www.anp.gov.br/i mages/Palestras/Camera_Brasil_Espanha_Decio_Oddone_04_12_2017.pdf

Oddone, D. (2018). Discurso do diretor-geral da ANP na cerimônia sobre os Avanços no setor de óleo e gás - Ciclo 2016-2018. Recuperado de http://www.anp.gov.br/palestra/4988discurso-do-diretor-geral-da-anp-na-cerimonia-sobre-os-avancos-no-setor-de-oleo-e-gas-ci clo-2016-2018

Oddone, D. (2019). Finalmente um mercado de gás natural no Brasil. FGV Energia. Recuperado de http://bibliotecadigital.fgv.br/dspace/bitstream/handle/10438/30219/coluna_opiniao_-_fin almente_um_mercado_-_decio_oddone_0.pdf? sequence $=1 \&$ isAllowed $=y$

Peltzman, S. (1976). Toward a more general theory of regulation. The Journal of Law \& Economics, 19(2), 211-240.

Péres, J. C., Santos, G. R. dos e Pompermayer, F. M. (2010). Biocombustíveis no Brasil: Etanol e biodiesel. In B. Pêgo e C. A. S. Campos-Neto (Orgs.), Infraestrutura Econômica no Brasil: Diagnósticos e perspectivas para 2025: Vol. I (p. 193-249). Brasil: Ipea.

Petrobras (2014). Volumes excedentes da Cessão Onerosa. Recuperado de https://petrobras.com. $\mathrm{br} /$ fatos-e-dados/volumes-excedentes-da-cessao-onerosa.htm

Petrobras (2018). Fechamos acordos com autoridades nos Estados Unidos e manteremos 80\% do valor no Brasil. Recuperado de https://petrobras.com.br/fatos-e-dados/fechamos-acordoscom-autoridades-nos-estados-unidos-e-manteremos-80-do-valor-no-brasil.htm

Peyerl, D. (2014). A contribuição do Conselho Nacional do Petróleo e da Petrobras na formação de profissionais para a exploração do petróleo no Brasil (Tese de Doutorado). Universidade Estadual de Campinas. Recuperado de http://repositorioslatinoamericanos.uchile.cl/handle/2250/1318317

Philip, G. (1982). Oil and Politics in Latin America Nationalist Movements and State Companies. Cambridge: Cambridge University Press.

Posner, R. A. (1974). Theories of economic regulation. The Bell Journal of Economics and Management Science, 5(2), 335-358. 
Projeto Memória. (1998). Monteiro Lobato na Web. Recuperado de http://www.projetomemoria. art.br/MonteiroLobato/index2.html

Quintans, L. C. (2012). A trajetória do monopólio do petróleo no Brasil. Recuperado de https://do cero.com.br/doc/ns80s5e

Quintans, L. C. (2016). Alterar a Lei da Partilha da Produção é entregar o Pré-sal aos estrangeiros? Recuperado de https://quintans1.jusbrasil.com.br/artigos/394722151/alterar-a-lei-dapartilha-da-producao-e-entregar-o-pre-sal-aos-estrangeiros

Reis, C. M. (2020). Das margens do Maraú no Brasil imperial à criação da Petrobras: 100 anos de geo-história do petróleo nacional. Geo UERJ, 37, e48493. DOI: 10.12957/geouerj.2020.48493

Richardson, R. J. (2015). Pesquisa Social: Métodos e Técnicas (3a. ed.). Brasil: Atlas.

Smith, P. S. (1978). Petróleo e política no Brasil Moderno. Brasil: Artenova.

Stigler, G. J. (1971). The Theory of Economic Regulation. The Bell Journal of Economics and Management Science, 2(1), 3-21. DOI: 10.2307/3003160

Supremo Tribunal Federal - STF. (2005). Ação Direta de Inconstitucionalidade-ADI 3273. Recuperado de https://stf.jusbrasil.com.br/jurisprudencia/14739210/acao-direta-de-inconstituc ionalidade-adi-3273-df/inteiro-teor-103124721

Szmrecsányi, T. e Sá, A. C. (2001). Dicionário histórico-biográfico brasileiro, pós-1930 (2. ed. rev. e atualizada; C. J. de Paula \& F. Lattman-Weltman, Orgs.). Rio de Janeiro: Fundação Getúlio Vargas/Centro de Pesquisa e Documentação de História Contemporânea do Brasil.

Thomas, J. E. (2001). Fundamentos de engenharia de petróleo. Rio de Janeiro: Interciência.

TN Petróleo. (2017). CPNE define regras para 15a, 16a, 4a e 5a rodadas no regime de partilha de produção no pré-sal. Recuperado de https://npetroleo.com.br/noticia/cpne-define-regraspara-15a-16 a-4a-e-5a-rodadas-no-regime-de-partilha-de-producao-no-pre-sal

Twichell, J. (2015). The Political Economy of Hydrocarbon Sector Development Policy: A Comparative Case Study of Argentina, Brazil, and Mexico (Tese de Doutorado). University of Miami, Miami. Recuperado de https://scholarship.miami.edu/discovery/fulldisplay/alma99103144772390 2976/01UOML_INST:ResearchRepository

U. S. Energy Information Administration. (2021). Europe Brent Spot Price FOB (Dollars per Barrel). Recuperado de https://www.eia.gov/dnav/pet/hist/rbrteM.htm

Vieira, J. E. R. F. e Fishlow, A. (2017). Agricultura e indústria no Brasil: Inovação e competitividade. Brasil: Ipea.

Walle, N. van de. (1989). Privatization in developing countries: A review of the issues. World Development, 17(5), 601-615. DOI: 10.1016/0305-750X(89)90062-4

Westin, R. (2014). Criação da Petrobras rachou Senado em 1953. Jornal do Senado, 7. 